\title{
Contributions
}

David Granlund*

\section{The Effect of Pharmacies' Right to Negotiate Discounts on the Market Share of Parallel Imported Pharmaceuticals}

\begin{abstract}
This paper analyzes how allowing pharmacies to negotiate discounts with parallel traders and producers affects the market share for parallel imports. Economic theory predicts that discount negotiations will promote products bought directly from the producers because producers have cost advantages, due to which they always underbid the marginal prices of parallel traders. A reform that allowed discount negotiations is found to reduce the market share for parallel imports by about 11 percentage points to reach $31 \%$. The results clearly indicate that pharmacies have an important role in the choice between medically equivalent pharmaceuticals.
\end{abstract}

Keywords: drugs, incentives, margins, parallel imports, parallel trade, pharmacies

JEL Classification: I11, I18, L13, L51, L65

DOI 10.1515/bejeap-2014-0079

\section{Introduction}

Parallel import can arise when a producer sell products at different prices to wholesalers in different countries. For example, in an attempt to price discriminate, Pfizer might charge less from wholesalers in low-income countries than it charges for the same product from wholesalers in high-income countries. Parallel traders can take advantage of the price differences by buying products intended for low-price countries and selling them to wholesalers in high-price countries. Parallel trade is allowed within the European Economic Area (the 27 EU member states and Iceland, Liechtenstein and Norway) toward fulfilling the

*Corresponding author: David Granlund, Department of Economics, Umeå University, SE-901 87 Umeå, Sweden, E-mail: david.granlund@econ.umu.se 
objective of creating a single market and parallel traders do not require authorization of the patent holder. In the United States, the Supreme Court recently held parallel trade to be legal under certain circumstances in a 6-3 decision (Kirtsaeng v. John Wiley \& Sons, Inc., No. 11-697, U.S. Mar. 19, 2013).

The purpose of this paper is to study the pharmacies role in the choice between medically equivalent pharmaceuticals. In particular, the paper analyzes how a reform that allows pharmacies to negotiate discounts with producers and parallel traders affects the probability that parallel imported products are sold. To reduce the costs of prescription drugs, pharmacies in most countries have a right or obligation to suggest substitution of prescribed drugs with cheaper, generic or parallel imported substitutes. Pharmacies have a potentially large impact on pharmaceutical costs since their information to consumers about generics and parallel imports and the extent they keep them in stock influences which products that are sold. Still, to the best of my knowledge, only Brekke, Holmås, and Straume (2013) have studied the pharmacies' role in promoting cheaper alternatives.

Brekke, Holmås, and Straume (2013) analyzed the brand-name market shares for off-patent drugs in Norway. Using monthly data on average margins for brand name and generics for different substances and pharmacy chains, they found that the brand-name market shares were positively related to the margins on brand names and negatively related to the margins on generics. This paper complements Brekke, Holmås, and Straume's (2013) by studying the effects of a reform that changed pharmacies' incentives and by analyzing the other part of the market, that for on-patent drugs. Another contribution is that the data allow me to study which measures pharmacies take to affect the market shares. The paper also contributes to the general literature analyzing retailers' incentive to steer consumers to buy goods on which they earn relatively high margins (e.g. Raskovich 2007).

When producers and parallel traders are able to condition discounts on quantities, they are in principle able to practice first-degree price discrimination although constrained by maximum prices set by the government. This means that a producer that knows a pharmacy's demand function for its product for a given offer by the parallel traders can offer the pharmacy a discount-quantity combination where the producer get paid the pharmacies entire willingness to pay for the part of the quantity where the marginal willingness to pay does not exceed the regulated maximum price. Parallel traders will have a cost disadvantage, since they in addition to buying products that are initially sold by the producers have cost for repacking and trading. Therefore, the simple theoretical model derived in this paper shows that when discounts are allowed, it will be profitable for sellers of locally sourced products (i.e. products that are sold directly 
to wholesalers in the country where they are bought by consumers) to give large enough discounts so that pharmacies sell their products to all consumers that prefer these or are indifferent between these and parallel imported products. Locally sourced products will also be of interest to consumers who would, without costly persuasion by pharmacy personnel, be prepared to pay more for a parallel imported product, if only both were available at the pharmacy. ${ }^{1}$

The empirical analyses are based on prescription-level data from the county of Västerbotten, Sweden, for the years 2007-2011. On July 1, 2009, pharmacies got the right to negotiate discounts on the wholesale prices of pharmaceuticals without generic substitutes, while a government agency continued to determine maximum wholesale and retail prices. Before that date, pharmacies' margins were determined by the government agency, and nearly identically for locally sourced and parallel imported products. Pharmacies also got the right to sell parallel imports at prices lower than the maximum retail prices, but the data reveal that this possibility was almost never used.

On July 1, 2009, it also became legal to open private pharmacies in Sweden, and the following months more than half of the government-owned pharmacies were sold out. The data identify pharmacy chains, which enable me to study differences between pharmacies that were kept in government ownership and private pharmacies.

In accordance with the theoretical predictions, parallel importers do not seem to be able to match with the offers of producers. The results show that the reform has reduced the market shares of parallel imports by about 11 percentage points, from $42 \%$ to $31 \%$. There is heterogeneity across pharmacy chains, but on average the private pharmacy chains are nearly as likely as the remaining government-owned pharmacies to sell parallel imports. The results support the conclusion of Brekke, Holmås, and Straume's (2013) that pharmacies have indeed an important role in determining which products that are sold.

The largest part of the reduction in the market share of parallel imports is achieved due to that pharmacies after the reform are less likely to offer

1 Most consumers likely prefer locally sourced products, for example, because of more familiar trade names. However, because of consumer inertia (Coscelli 2000; Dubé, Hitsch, and Rossi 2010) and/or that a parallel imported version is prescribed, some consumers do prefer parallel imported version. One-fourths of prescriptions analyzed in this study were for parallel imported products. That some physicians prescribe parallel imported products is likely explained by the fact that locally sourced and parallel imported versions are listed separately by the computer system physicians use to write prescriptions. Some physicians say that they just choose the first product on the list of medically equivalent products. The results in Granlund and Rudholm (2012) as well as in the present paper indicate that many consumers prefer to buy the product written on prescription. 
consumers cheaper parallel imported alternatives. However, a part of the reform effect is explained by that consumers have become more likely to buy locally sourced products despite that they are prescribed parallel imported products and that such products are available at the pharmacy. This indicates that the reform has increased the probability that pharmacies inform consumers about their right to buy other substitutes than the prescribed product or the cheapest available substitute.

This paper relates to many studies on determinants of choices between medically equivalent pharmaceuticals (Leibowitz, Manning, and Newhouse 1985; Hellerstein 1998; Coscelli 2000; Mott and Cline 2002; Granlund 2009) even though these studies have focused on the choice between brand name and generics and primarily analyzed the role of physicians. Using survey data on 3,000 prescriptions from pharmacies in a Midwestern state, Mott and Cline (2002), however, found that pharmacy random effects accounted for $43 \%$ of the variation in the occurrence of generic substitution. This might, like the results of Brekke, Holmås, and Straume (2013), indicate that pharmacies have an important role in determining whether a cheaper alternative is dispensed, but the random effects might also capture local variations in consumers' attitudes toward generics.

The theoretical literature regarding parallel trade includes Pecorino (2002), Ganslandt and Maskus (2004), Maskus and Chen (2004), Jelovac and Bordoy (2005) and Chen and Maskus (2005), which show, among other things, that parallel imports should create price competition and cause prices to fall in the high-price country. This is supported empirically by Ganslandt and Maskus (2004) who found that competition from parallel imports reduced prices on locally sourced drugs by $12-19 \%$. On the other hand, Kanavos and Costa-Font (2005) estimated the effect of the market share of parallel imports on price competition and found no statistically significant effect.

Section 2 presents the theoretical model. Section 3 describes institutional characteristics of the Swedish pharmaceutical market with special focus on the pharmacy reform, and Section 4 describes the data. The empirical analyses, including hypotheses to be tested, specifications and results, are presented in Section 5. Finally, Section 6 concludes the paper.

\section{Theoretical Model}

This section analyzes pharmacies' marginal purchase prices and the market shares for locally sourced and parallel imported products when pharmacies can get discounts. Note that producers and parallel traders can condition 
discounts on quantities sold which enables them to set marginal prices below their average prices. $^{2}$

Assume that there is one low-price (low-income) country where a parallel trader buys parallel imports and one high-price (high-income) country where the parallel imports are sold. In the high-price country, there is one pharmacy selling one drug for which there is one locally sourced product and one parallel imported product. In the high-price country, there is a continuum of consumers normalized to unity, each consumer buying one package of the drug, which implies that the total demand is also normalized to unity. In this country, the government has set a fixed retail price for the locally sourced product normalized to 1 and an equally high maximum retail price for the parallel imported product. ${ }^{3}$

Let $p_{s}$ be the price the producer charges from the wholesaler in the low-price country. The producer's profit will increase if the pharmacy sells more locally sourced products instead of parallel imports as long as the producer's revenue on the marginal unit exceeds $p_{s}$. At the margin, the producer is, therefore, prepared to sell at $p_{s}$. To see this, let $q_{s}$ denote the demand in the low-price country, $q_{l s}$ the pharmacy demand for locally sourced products in the high-price country, $R$ the producers' revenues from $q_{l s}$, and $m p$ the marginal wholesale price on locally sourced products in the high-price country. Note that $q_{l s}$ depends on $m p$ and the marginal wholesale price on parallel imported products in the high-price country, which in turn is a function of $p_{s}$. Therefore, $q_{l s}$ can be written as a function of $p_{s}$ and $m p$. The producer's profit function can then be written as

$$
\pi=p_{s}\left[q_{s}\left(p_{s}\right)+1-q_{l s}\left(p_{s}, m p\right)\right]+R\left(p_{s}, m p\right),
$$

where $R=\int_{0}^{q_{l s}\left(p_{s}, m p\right)} P(i) d i$ is the total revenue from locally sourced products sold in the high-price country. The first-order condition with respect to $m p$ becomes

$$
\frac{\partial \pi}{\partial m p}=\left(-p_{s}+\frac{\partial R}{\partial q_{l s}}\right) \frac{\partial q_{l s}}{\partial m p}=0 .
$$

2 Note that this situation is fundamentally different as compared to one where the negotiation is only about an official list price. Sellers of locally sourced products are less likely to reduce their official price in a country than to give discounts since a lower official price implies: (1) lower revenues from the quantity they anyway would have sold in that country, (2) lower revenues from other countries where the official price from the country in question is used as an external reference price and (3) lower revenues from countries which could become recipients of parallel imports from the country in question. Depending on the rules in the country, it might also be more difficult to increase an official price than to reduce a discount, which is a fourth argument in favor of giving a discount instead of lowering the official price.

3 This is consistent with the rules in Sweden where pharmacies after the reform are allowed to sell parallel imports, but not locally sourced products, at lower prices than those determined by the Dental and Pharmaceutical Benefits Agency. 
Assuming $\frac{\partial q_{l s}}{\partial m p} \neq 0$, this only holds if $\frac{\partial R}{\partial q_{l s}}=p_{s}$. Note that the marginal revenue in the high-price country equals what the producer charges for the last package since the producer can condition discounts on quantity; thus, $\frac{\partial R}{\partial q_{l s}}=m p=p_{s}$. For an analysis of the price setting in the low-price country, see, e.g. Jelovac and Bordoy (2005). For the purpose of this paper, it is sufficient to assume that $p_{s}$ is low enough for parallel trade to take place.

Let $r>0$ denote the sum of the extra transportation cost per package that occurs when the drug instead of being directly shipped to the high-price country first is shipped to the low-price country, the unit repacking cost and the margin of the wholesaler in the low-price country. The lowest price at which a parallel trader can sell the drug to the pharmacy in the high-price country without making losses is then $p_{s}+r$. Whether $r$ remains constant or increases with the demand for parallel imports does not affect the qualitative result of these analyses.

Since the producer, at the margin, is prepared to sell at $p_{s}$ while the parallel trader charges $p_{s}+r$, the pharmacy will never want to promote parallel imports. Therefore, the pharmacy will not sell the parallel import at a lower price than the maximum price. Thus, the prices of the parallel imported product will equal that of the locally sourced product.

In a simple case where all consumers consider the locally sourced and the parallel import product to be perfect substitutes, pharmacies would just buy the product that is cheaper. The Nash equilibrium of this Bertrand game is that the market share for the parallel import is zero and that the producer charge $p_{s}+r$ for each unit (see, e.g. Varian 1992, section 16.4, for a detailed explanation of this result).

\subsection{Heterogeneous Preferences}

Consumers do, however, have heterogeneous preferences. This can be caused by, for example, consumer inertia (see, e.g. Coscelli 2000; Dubé, Hitsch, and Rossi 2010) or by that many consumers prefer to get exactly the product written on the prescription (Granlund and Rudholm 2012).

Let us assume that the share of consumers buying the parallel imported product ( $m=1-q_{l s}$ ) depends on the effort (e) employed by the pharmacy, measured in monetary terms, to convince consumers to buy the locally sourced product and assume that $m^{\prime}(e)<0$ and that $m^{\prime \prime}(e)>0 .{ }^{4}$ Normalize the unit cost for $e$ to unity and let $C_{l s}(1-m(e))$ and $C_{p i}(m(e))$ be functions describing how

4 This assumption is inspired by Brekke, Holmås, and Straume (2013) who developed a model where pharmacies could affect consumers' perception of the quality degradation of generic drugs. 
pharmacies' total purchase cost for locally sourced and parallel imported products depend on $m$. Since both total demand and the retail prices equal 1 , the pharmacy's revenue equals 1 and its profit function can be written as

$$
\Omega=1-C_{l s}(1-m(e))-C_{p i}(m(e))-e .
$$

The pharmacy will choose $e \geq 0$ to maximize profits. Considering that the marginal prices offered by the producer and the parallel importer are $p_{s}$ and $p_{s}+r$, the Kuhn-Tucker conditions become

$$
\begin{gathered}
\frac{\partial \Omega}{\partial e}=-r \frac{\partial m}{\partial e}-1 \leq 0 \\
e\left(r \frac{\partial m}{\partial e}+1\right)=0
\end{gathered}
$$

Thus, the pharmacy will choose $e$ so that $m^{\prime}(e)=-1 / r$ or choose $e=0$ if $m^{\prime}(e) \geq$ $-1 / r$ (i.e. $\left.\left|m^{\prime}(e)\right| \leq 1 / r\right)$ already when $e=0$. If the solution is interior, it implies that the locally sourced product will not only be sold to those who without persuasion preferred that product or was indifferent between the two products, but that it will also be sold to some of the consumers that preferred the parallel imported product before coming to the pharmacy. Since $m^{\prime \prime}(e)>0$, the KuhnTucker conditions also reveal that, for interior solutions, the effort and hence the market share of locally sourced products is increasing in $r$. That is, the larger the cost advantage of the locally sourced product, and hence the larger the difference in marginal prices offered to the pharmacy, the smaller will be the market share for the parallel imported products.

It is quite reasonable that some consumers are easily persuaded by the pharmacy personnel to buy a certain product. On the other hand, some consumers have strong preference for a given product. In the data used in this paper, $11 \%$ of the consumers paying extra to get the product they preferred paid more than SEK 50 extra (approximately 6 Euros). Thus, it might seem reasonable to assume that $m^{\prime}(e)$ is initially negative enough so that the optimal $e$ is positive, and that $m^{\prime \prime}(e)$ is sufficiently positive so that the market share for the parallel imported product does not become zero. Pharmacies might, however, have other instruments at its disposal that are less costly than persuasion. One obvious candidate is raising the generalized price for the parallel imported product.

\subsection{Raising the Generalized Price of Parallel Imports}

The generalized price also includes the costs of consumers' traveling and waiting. The pharmacy can raise the generalized price for the parallel imported 
product by simply not keeping it in stock and telling consumers that if they insists of getting that product they have to come back to the pharmacy when the pharmacy have ordered and received that product.

When the total demand facing the pharmacy is exogenously given, as it is in this model, the cost of raising the generalized price for the parallel imported product is zero. Let us, however, assume that there is a limit for how much the generalized price can be raised. Such a limit might be caused by rules requiring the pharmacy to be able to dispense the product a consumer prefers within a few days. For example, the Swedish rules require that pharmacies should deliver prescribed pharmaceuticals they do not have in stock within 24 days unless special circumstance motivates longer time (Ministry of Health and Social Affairs 2009c).

The pharmacy will clearly raise the generalized price of parallel imports as much as possible, since this is costless. The increase in generalized price does not affect the way the Kuhn-Tucker conditions for $e$ are written, but it will affect the value of $m^{\prime}(e)$ when $e=0$ since the effort is directed toward another part of the population. Consumers who without persuasion are prepared to pay a higher generalized price (e.g. to come back to the pharmacy the next day) are perhaps less easily persuaded to buy the locally sourced product. That is, although adding the additional instrument will not alter the form of the Kuhn-Tucker conditions, it might reduce the absolute value of $m^{\prime}(e)$ so much that the optimum becomes a corner solution with $e=0$.

To sum up, the model shows that the marginal purchase price will be lower for the locally sourced product than for the parallel imported one. This implies that pharmacies will sell the locally sourced product to all that initially preferred that product or were indifferent between the two products, as well as to some of the consumers that initially preferred the parallel imported product. When total demand facing the pharmacy is inelastic, the pharmacy will increase the market share of the locally sourced product by increasing the generalized price of parallel imports. It is, however, not clear that the parameter values in reality are such that pharmacies in addition will devote efforts to persuading consumers to buy locally sourced products.

This model can also help us understand other markets where parallel importing is important. It does not, however, inform about pharmacies' incentives on off-patent pharmaceutical market since we do not know the relationship between brand-name firms' and generic firms' marginal costs.

\section{Institutional Setting}

All Swedish residents are covered by a mandatory and uniform pharmaceutical benefit scheme where the co-payment rate is a decreasing function of 
pharmaceutical cost and reaches zero when the costs exceed SEK 4300 during a 12-month period. In the data used for this study, consumers paid $17 \%$ of the total costs, and in $38 \%$ of the observations the consumers paid nothing.

Since October 2002, substitution of exchangeable products has been mandatory. Unless the physician prohibits substitution for medical reasons, ${ }^{5}$ pharmacy personnel are required to inform consumers if substitute products are available, and that the cheapest available substitute product will be provided within the Swedish pharmaceutical benefits scheme. If consumers oppose substitution or choose to switch to another substitute than the cheapest available, the entire extra cost will be charged to them. The Swedish Medical Products Agency defines a product as a substitute if it has the same active substance, strength and form (e.g. pills or oral fluid) as the prescribed product and if its package sizes can approximately sum up to the prescribed quantity. For parallel imports, available substitutes are defined as those in stock at the pharmacy in question (Dental and Pharmaceutical Benefits Agency 2009).6,7

Pharmaceutical producers and parallel traders are free to set their own prices, but in order to be included in the pharmaceutical benefits scheme, the price must be approved by the Dental and Pharmaceutical Benefits Agency Tandvårds och Läkemedelsförmånsnämnden (TLV). ${ }^{8}$ Parallel imports always are allowed as high price as locally sourced products (Pharmaceutical Benefits Agency 2003, 2006). For pharmaceuticals within the pharmaceutical benefits scheme, TLV determines maximum pharmacy purchase prices and, before July 2009, producers and parallel importers were not allowed to offer their products at prices below these price caps. For parallel imported products sold since July 1 , 2009, TLV determines maximum retail prices and for all other products within the pharmaceutical benefits scheme TLV determines the exact retail prices that must be charged by all pharmacies. The rules imply that TLV determines

5 If the physician prohibits the substitution, the consumer is still reimbursed based on the full price of the more expensive prescribed product. Physicians only prohibited substitution for $1.35 \%$ of the prescription in this dataset. The national average during October 2002 to December 2003 was 3\% (National Corporation of Swedish Pharmacies et al. 2004).

6 The effects of substitution reforms on prices and costs have been studied by Andersson et al. (2005), Granlund (2010), Granlund and Rudholm (2011) and Granlund and Köksal (2014).

7 Parallel imports have the same active ingredient in the same amount and the same dosage form (e.g. tablet or capsule) as the locally sourced pharmaceuticals. However, parallel imports might differ from true brands in packaging, or in some cases even in the name. For example, parallel imported Diovan Comp is marked as "Diovan Comp" as well as "Co-Tareg," one of the many trade names under which it is available in the EU. Similarly, parallel imported Nexium is marketed in Sweden both as "Nexium" and "Axagon."

8 The Dental and Pharmaceutical Benefits Agency (TLV) replaced the Pharmaceutical Benefits Agency (LFN) in July, 2008, when a dental care reform went into effect. 
guaranteed margins for the pharmacies and during the study period these were continuously increasing in the pharmacy purchase price. ${ }^{9}$ Pricing of both products outside the benefit scheme and merchandises is unrestricted (Pharmacy Restructuring Corporation 2009).

\subsection{The Pharmacy Reform}

Until January 2010, all prescription pharmaceuticals in Sweden were sold through a nationwide government-owned monopoly, Apoteket $\mathrm{AB}$, which at all times charged a nationwide uniform price for each pharmaceutical product.

On April 29, 2009, the Swedish parliament voted in favor of a new law allowing pharmacies, from July 1, 2009, to buy pharmaceuticals without generic substitutes at lower prices than those determined by TLV, if they can negotiate a discount with the sellers (Ministry of Health and Social Affairs 2009b). Pharmacies are also allowed to sell parallel imported pharmaceuticals without generic substitutes at lower prices than the retail prices determined by TLV. The government stated in the bill (Ministry of Health and Social Affairs 2008) that the purpose was to achieve cheaper parallel import and to increase the quantity of parallel imports. They expected that pharmacy chains would get discount on parallel imports but not on locally sourced products. It is not entirely clear why the government did not expect discounts on locally sourced products, but the government argues that the producers' strong negotiation positions would reduce the probability of them giving discounts. This would be true if producers' lacked interest to give pharmacies incentives to sell locally sourced products, but the government was informed by the Swedish Competition Authority and others that the producers might have such incentives (Ministry of Health and Social Affairs 2008).

Since July 1, 2009, also private pharmacies are allowed in Sweden (Ministry of Health and Social Affairs 2009a). In addition, the government decided to sell around half of Apoteket AB's pharmacies to Apotek Hjärtat, Kronans Droghandel, Medstop Apotek and Vårdapoteket. Of about 500 pharmacies remaining, 150 were reserved for sale to small businesses by transferring them to a government-controlled company, Apoteksgruppen. On January 17, 2010, the first new pharmacy company started running a pharmacy, which was a

9 For patent-protected pharmaceuticals, the maximum retail price in SEK (RP) depended on the maximum wholesale prices in SEK (PP) according to the formula: $\mathrm{RP}=\mathrm{PP} \times 1.20+31.24$ if $\mathrm{PP} \leq 75, \mathrm{RP}=\mathrm{PP}^{\star} 1.03+44.00$ if $75<\mathrm{PP} \leq 300, \mathrm{RP}=\mathrm{PP}^{\star} 1.02+47.00$ if $300<\mathrm{PP} \leq 6000$, $\mathrm{RP}=\mathrm{PP}+167.00$ if $\mathrm{PP}>6000$. 
pharmacy bought from Apoteket AB. The overall purpose of the pharmacy reform was to improve the availability of pharmaceuticals (by increasing the number of pharmacies and prolonging opening hours), improve service to customers, improve supply of services and to achieve lower pharmaceutical costs (The Committee on Health and Welfare 2009).

\section{Data and Descriptive Statistics}

The prescription dataset used in this study was provided by the county council of Västerbotten. It contains all prescriptions sold in Sweden to residents of the county, from January 2007 through December 2011. Similar datasets covering 2000-2006 were used to identify the first month parallel imported version of a drug was sold to the residents of Västerbotten. The datasets were merged with datasets from IMS Health containing indicators for parallel imported and generic products, patent expiration dates, national sales figures and names of firms that sold each product to wholesalers in Sweden.

Prescriptions of pharmaceuticals packed in patient doses were excluded since patients were not asked if they opposed substitution in these cases. Nonpharmaceutical prescriptions were excluded from the analyses as well as prescriptions for vitamins, minerals, orphan drugs and drugs that were not approved for the Swedish market and only could be sold to patients for whom the Swedish Medical Products Agency had granted an exception. Also prescriptions for drugs not included in the pharmaceutical benefit scheme were excluded since the price setting for these drugs is unrestricted.

As stated above, the price regulations differ depending upon if the pharmaceuticals are exchangeable toward generics. Therefore, the study excluded products that active substance lacked patent protection. This implies that, besides excluding drugs with direct generic competition, drugs with potential generic competition and drugs that are close, but not perfect, substitutes with generic products were also excluded. With this exclusion criterion, I avoid having to control for changes in demand and prices that can occur due to potential direct or indirect generic competition. ${ }^{10}$

The observations where the prescriber has opposed substitution were also excluded, since pharmacies and consumers in these cases could not choose

10 If generic products of drug $j$, with the same active ingredient but different strength and/or form than drug $i$, became available, drug $i$ likely loses a part of price-sensitive consumers, which might negatively affect the market share for parallel imported products of drug $i$. To estimate this effect is beyond the scope of this paper. 
which product that was dispensed. This reduced the population size by $1-2 \%$ each month after which nearly 2 million prescriptions remain. These prescriptions were for over a 1,000 different drugs where a drug is defined as a unique active substance-strength-form combination. Thus, there can be different package sizes of a drug. For many of the drugs with relatively less sales, no parallel imported product was sold during the study period. The study used fixed drugspecific effects in the analyses, which means that these drugs are excluded from the analyses. This leaves us with 675,648 prescriptions for 218 different drugs.

Table 1 presents descriptive statistics for the entire population as well as separately for prescriptions of locally sourced products (LS) dispensed before July 2009 and dispensed from March 2010, respectively, and prescriptions of parallel imported products $(P I)$ for the same two periods. Observations are weighted using the average of the product prices as weight. For the indicator variables, the percentage belonging to each category is presented, and for continuous variables, means and standard deviations are presented.

The variable PI takes the value 1 in the $37 \%$ of the observations when a parallel imported product was dispensed. When a parallel import is prescribed, such products are dispensed in $83 \%$ of the observations before July 2009 and in $71 \%$ of the observations from March 2010. This indicates that the prescribers' choice among medically equivalent products might be important despite that pharmacies should suggest substitution if cheaper alternatives are available and also that the share that buy a locally sourced product despite that a parallel imported product is prescribed is considerably larger after the reform. Reform takes the value 1 from July 2009 when discounts were allowed, and March2010 takes the value 1 from March 2010 when the new pharmacy chains had taken control over previously government-owned pharmacies. Euro is the monthly average of number of SEK required to buy 1 Euro, and Time is the number of days from the start of the study period.

PI_presc takes the value 1 in $24 \%$ of the observations when a parallel imported product was prescribed. Information on PI_presc is missing for about 13,000 prescriptions. NotMD equals 1 in the few cases when the prescription was written by someone other than a medical doctor (e.g. a dentist or a nurse). Child indicates that the prescription was for a patient 15 years or younger. Table 1 further shows that the mean age of patients was 59 years, and that $53 \%$ were women. CMonth indicates in which of the 12 calendar months the prescription was dispensed.

Demand LS equals 1 if the consumer paid extra to get a locally sourced product instead of a parallel imported product that is cheaper. Table 1 reveals that this is more common when locally sourced products are prescribed and after the reform. When parallel imported products are prescribed, pharmacies 


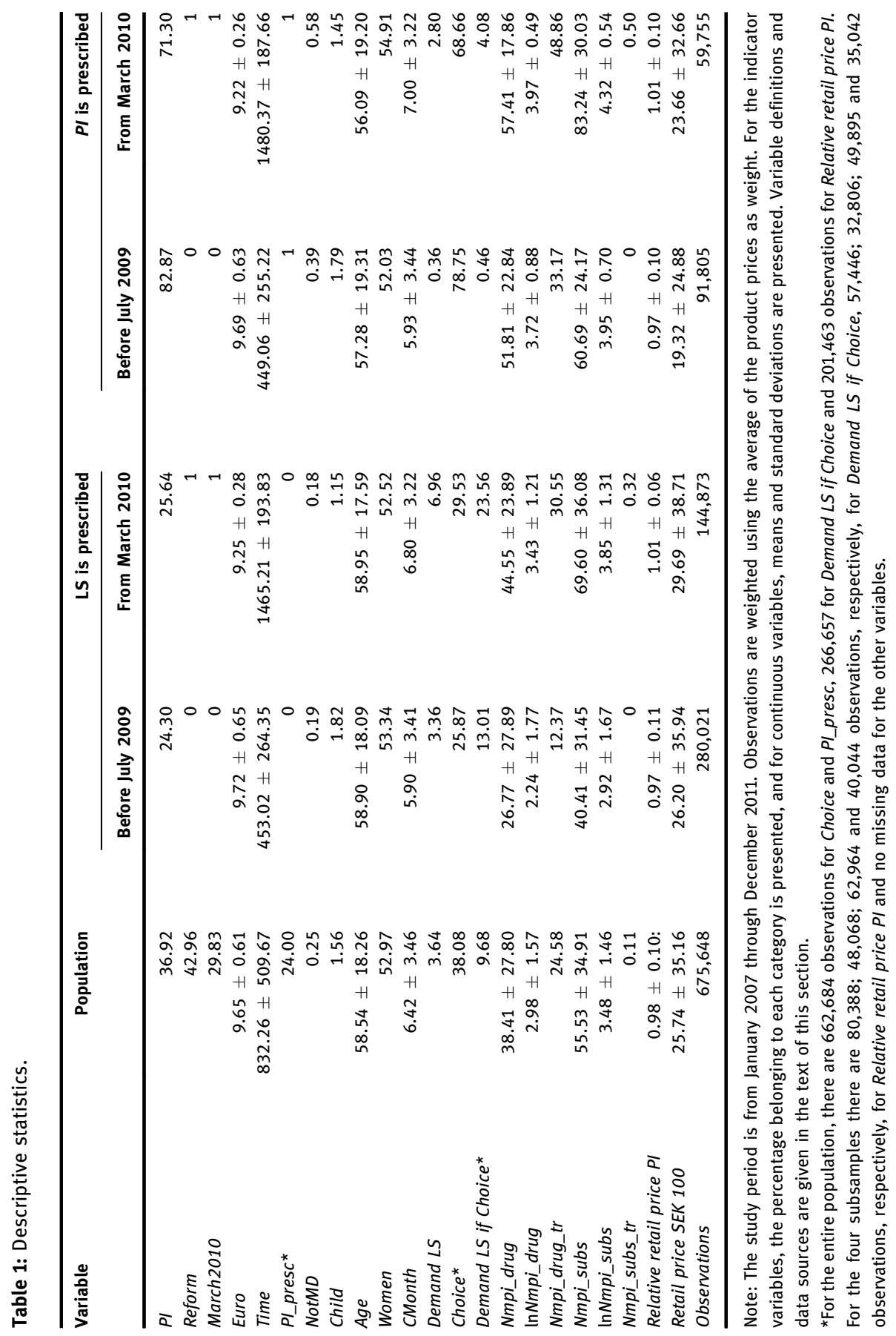


are not required to inform consumers that they can get the locally sourced product if they pay the price difference, but still Demand $L S$ equals 1 for $3 \%$ of the prescriptions of parallel imported products dispensed from March 2010.

Choice is an indicator variable that takes the value 1 if the consumer has an opportunity to buy a parallel imported product that is cheaper than the locally sourced one. We see that consumers had this opportunity more often for prescriptions for parallel imports than for prescriptions for locally sourced products. Choice takes the value 1 if $P I=0$ and Extra $=1$, where Extra is a variable from the prescription dataset that equals 1 if the consumer paid extra to get some other product than the cheapest available. Choice also takes the value 1 if $P I=1$ and the parallel imported product was cheaper than the locally sourced product. Thus, in the $6 \%$ of the cases when a sold parallel imported product was as expensive as or more expensive than the locally sourced product, Choice was coded as 0 . In nearly $20 \%$ of the observations where a parallel imported product was sold, the relative price is unknown. For these observations, Choice is coded as 1 , but in some robustness analyses, these observations are instead excluded. Demand LS if Choice reveals that of the consumers who were prescribed a locally sourced product and had a choice 13\% before July 2009 and 24\% from March 2010 paid extra to get the locally sourced product instead of a cheaper parallel imported alternative. The corresponding figures for consumers who were prescribed parallel imported products are 0,5\% before July 2009 and 4\% from March 2010.

Nmpi_drug is defined as the number of months since a parallel imported product of the drug was first sold to a resident of Västerbotten. It is truncated at 72 due to lack of access to variables that identify drugs before January 2000. If a parallel imported product is not sold before the current month, Nmpi_drug is 0 and so is lnNmpi_drug, which otherwise is defined as the natural logarithm on Nmpi_drug. Nmpi_drug_tr indicates that these two variables are truncated. NMpi_subs, InNMpi_subs and NMpi_subs_tr are defined correspondingly as measures of the number of months since a parallel imported product of a given substance was sold in Sweden, but NMpi_subs and InNMpi_subs are truncated at 131. Table 1 shows that all these six variables have higher means for prescriptions of parallel imports than for prescriptions of locally sourced products, which indicates that physicians are more likely to prescribe parallel imported products that have been available for a long time.

The descriptive statistics for Relative retail price PI indicate that before the reform parallel imported products were on average 3\% cheaper than locally sourced products. This variable is, however, only defined for the 201,463 observations where a locally sourced product is bought and an exchangeable parallel imported product with the same package size is sold the same month. The 
higher price led to that pharmacies' margins, on average, were $1 \%$, or SEK 0.75 (approximately Euro 0.08), lower on parallel imports. The margins on parallel imports were more than $5 \%$ lower in only $5 \%$ of the observations. The discounts given after the reform are trade secrets, so pharmacies' margins after the reform are unknown. From March 2010 parallel imported products were instead on average $1 \%$ more expensive. Still some parallel imported products remained cheaper which can be explained by that it can be in the parallel traders' incentive to have lower prices and since it is the parallel traders, not the pharmacies, who suggest the maximum prices to TLV.

Retail price SEK 100 is the retail price of the dispensed product in hundreds of Swedish crowns. That the retail prices are lower when parallel imported products are prescribed is likely explained by that these are more often prescribed for old drugs which commonly have lower prices. Since the numbers for Retail price SEK 100 are significantly affected by the composition of products in each sample, they say little about how prices evolve. To study this, I instead regressed the natural logarithm of the retail price level of locally sourced products on product fixed effects and year-month indicators. The results show that then prices were as highest, in February 2006, they were only 1.5\% higher than in the month with the lowest price level, March 2009. Also, the results show that the price level of locally sourced products increased with less than $0.3 \%$ from the month preceding the reform, June 2009, to the end of the study period. ${ }^{11}$ Acorresponding regression for parallel imported products shows that prices in October 2010 were 6.7\% higher than in September 2006, and that the price increase from June 2009 to December 2011 was 2.85\%. The data also reveal that pharmacies in Västerbotten in less than $1 \%$ of the cases used the right to sell parallel imports at lower prices than the maximum price. Dental and Pharmaceutical Benefit Agency (2012) stated that pharmacies never used the right to sell parallel imports at lower prices and explained this with that consumers are not that price-sensitive because of the pharmaceutical benefit scheme.

For five key variables, the development over time is illustrated in Figure 1. To fit on the same scale, Euro is here divided by 20. Figure 1 reveals a clear positive trend in the share of consumers opposing to substitute prescribed locally sourced products for parallel imports. We also see that the Swedish currency was unusually weak relative to the Euro in 2009, and at least for part

11 Regressing the natural logarithm of the retail price of locally sourced product on product fixed effects, a linear time trend and a reform dummy, indicate that the reform did not affect these retail prices at all; the point estimate for the reform dummy was 0.0009 with a $95 \%$ confidence interval of -0.0005 to 0.0023 . Excluding the first and the last 18 months of the data give a similar result. 


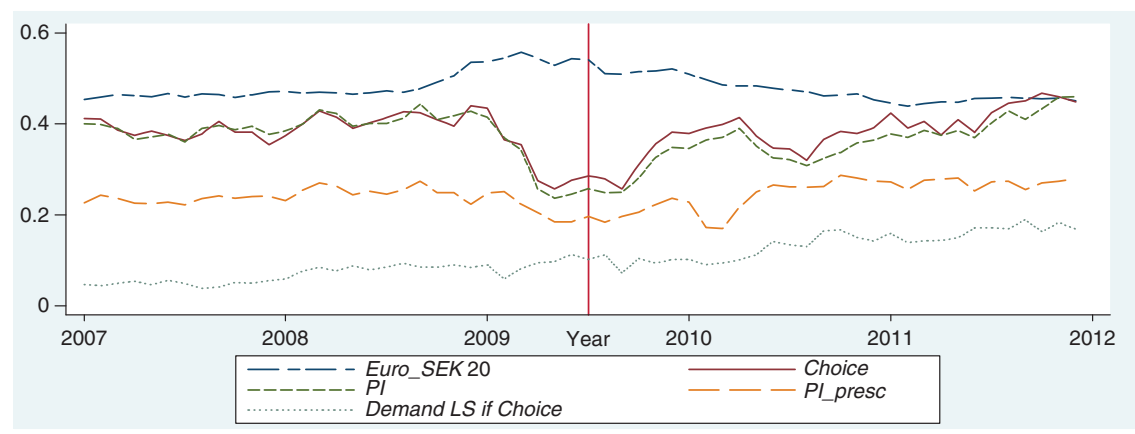

Figure 1: Key variables.

of that year there was a drop in Choice, PI and Pi_presc. Around the time of the reform, $P I$ and Choice started to increase, but this reveals little about the reform effect since this is likely, at least partly, explained by the decrease in Euro which started around the same time and made it more profitable to import to Sweden.

Table 2 presents the weighted percentage of observations dispensed in March 2010 or later belonging to 10 different pharmacy categories: three single pharmacies (Bramsäter Medicalshop $\mathrm{AB}$, Malå private and Norsjö private), six pharmacy chains and one group (Other) including single pharmacies and pharmacy chains outside the county. We see that the three pharmacy chains, Apoteket AB (government owned), Apotek Hjärtat and Kronans Droghandel, together had a market share of $96 \%$.

Table 2: Average post-reform market shares.

\begin{tabular}{lr}
\hline Apoteket AB & 34.17 \\
Apoteket Farmaci AB & 0.50 \\
Apotek Hjärtat & 24.12 \\
Apoteksgruppen & 1.31 \\
Bramsäter Medicalshop AB & 0.34 \\
DocMorris & 0.60 \\
Kronans Droghandel & 37.59 \\
Malå private & 0.54 \\
Norsjö private & 0.51 \\
Others & 0.32 \\
\hline
\end{tabular}

Note: The study period is from January 2007 through December 2011. Observations are weighted using the average of the product prices as weight. The percentage belonging to each category is presented. 


\section{Empirical Analyses: Hypotheses, Specifications and Results}

\subsection{The Market Share for Parallel Imports}

The theoretical model predicts that pharmacies after the reform will have lower marginal purchase prices for locally sourced products, and therefore have higher marginal margins on locally sourced products, since these are not sold at lower prices than parallel imported products. Before July 2009, the pharmacies' margins were nearly the same for locally sourced and parallel imports. Therefore, in accordance with the theoretical model, the main hypothesis is that the market share for parallel imports has been reduced by the reform.

This hypothesis is tested by estimating how the reform has affected the probability that a consumer buys a parallel imported product. The reform can have affected the probability that a pharmacy has a parallel imported product in stock and/or the probability that a consumer chooses to by that product if it is in stock. The mechanisms are analyzed later, but to test the main hypothesis, the total reform effect, irrespective of its mechanism, is first estimated.

The baseline specification (specification 1) used to test the main hypothesis is

$$
\begin{aligned}
\operatorname{Pr}\left(P I_{i}=1\right)= & F\left(\beta_{1} \text { Reform }_{i}+\sum_{c=2}^{10} \gamma_{c} \text { Chain }_{c i}+\beta_{2} \text { Euro }_{i}+\beta_{3} \text { Time }_{i}+\beta_{4} \text { PI_presc }_{i}\right. \\
& +\beta_{5} \text { NotMD }_{i}+\beta_{6} \ln \text { Nmpi_drug }_{i}+\beta_{7} \text { Nmpi_drug_tr }_{i}+\beta_{8} \ln \text { Nmpi_subs }_{i} \\
& +\beta_{9} \text { Nmpi_Subs_tr }_{i}+\beta_{10} \text { Child }_{i}+\beta_{11} \text { Age }_{i}+\beta_{12} \text { Age }_{i}^{2}+\beta_{13} \text { Women }_{i} \\
& \left.+\sum_{r=2}^{15} \rho_{r} \text { Mun }_{r i}+\sum_{m=2}^{12} \theta_{m} \text { CMont }_{m i}+\sum_{d=2}^{218} \alpha_{d} \text { Drug }_{d i}+\varepsilon_{i}\right),
\end{aligned}
$$

where $\mathrm{Mun}_{r}$ indicates the municipality of residence of the consumer. In all specifications, observations are weighted using the average of the product prices as weight. Unless otherwise noted, prescriptions dispensed during the reform period, July 1, 2009, to February 28, 2010, were excluded and the estimations were conducted using a maximum-likelihood logit estimator where the error terms $\left(\varepsilon_{i}\right)$ were allowed to be heteroskedastic and correlated within months.

The reform indicator captures the reform effect for the pharmacies that Apoteket $\mathrm{AB}$ continued to own. The indicators for the other pharmacy categories $\left(\right.$ Chain $\left._{c}\right)$ are included to study differences between the private pharmacies and the government-owned Apoteket AB. Note that Chain $\mathrm{c}$ is identical with 
interaction terms between Chain $_{\mathrm{c}}$ and the reform indicator since Apoteket $\mathrm{AB}$ was the only pharmacy chain before the reform. Therefore, the effects of other pharmacy categories are considered to be part of the total reform effect.

I control for the Euro exchange rate since many parallel importers have a large part of their transportation and repacking costs in Euros and since possible margins of wholesalers in source countries in most cases are in Euros. ${ }^{12}$ When Euro takes a high value (i.e. the Swedish currency is weak), parallel traders' expenses measured in Swedish Kronas will increase. Therefore, they will find it less profitable to import to Sweden and, according to the theoretical model, charge a higher marginal price if they import. Because of both these mechanisms, a negative effect of Euro is expected.

Time controls for a linear time trend in the probability that a parallel imported product is dispensed. I control for if a parallel imported product is prescribed (PI_presc) since some consumers prefer to get exactly what is prescribed. NotMD is included since the consumers' attitude toward substitution might depend on perceptions about the prescriber's ability to evaluate different pharmaceutical treatments.

The variables lnNmpi_drug, Nmpi_drug_tr, lnNmpi_subs and Nmpi_subs_tr are included since the results of Mott and Cline (2002) and Ching (2010) indicate that the time a product has been available has a positive effect on the probability that it is bought. Note that since the natural logarithm of 1 is 0 , none of these variables changes value the first time a parallel import is bought, which means that there is no risk of within-observation endogeneity. ${ }^{13}$

The variables describing the consumer's age, gender and municipality of residence are included to control for differences in consumer mix across pharmacy categories. I control for the calendar month the prescription was dispensed

12 A large part of the transportation cost is assumed to be in Euros since important source countries like Italy, Greece and Spain all use Euros and since transportation between many of the source countries and Sweden likely goes through countries that either have adopted the Euro or have fixed their exchange rates to the Euro. The majority of parallel imported pharmaceuticals sold in Västerbotten were repacked in Denmark that has fixed their exchange rate to the Euro. Other important repacking countries are Poland and Great Britain, but the exchange rates against the Zloty and Pound sterling had no significant effect and had only minor effect on the results and were, therefore, omitted.

13 Since the variables can be functions of previous values of the dependent variable within the study period and since drug-specific effects are included, an endogeneity problem of the same type as when lagged dependent variables are included in panel data estimations might exist. As Baltagi (2001) explains, the endogeneity problem is decreasing in the number of observations per fixed-effect unit. In this case, the average number of observations per drug exceeds 3,000, implying that the problem should be negligible. 
because the first 6 calendar months are overrepresented before the reform (because the rules were changed in July and not in January). The drug-specific fixed effects control for time-invariant differences between the drugs. This includes difference in the severity of the conditions the drug is prescribed against, which might affect that probability that consumers accept a parallel import. The drug-specific effects also partly control for the variation in quantities sold and price differences for locally sourced products between Sweden and other countries in the European Economic Area, which affects the probability that products are parallel imported.

I do not control directly for the relative consumer prices of locally sourced and parallel imported alternatives, since when a locally sourced product is dispensed one cannot know which parallel imported alternatives were available at the pharmacy and the prices of these. Another reason is that the relative prices are affected by the reform and, therefore, cannot be included as an exogenous explanatory variable. The relative prices that are available do not indicate any important changes over time apart from what can be controlled for by the linear time trend and that caused by the reform, which suggests that not controlling for relative prices does not bias the estimators.

The results of specification 1 and three alternative specifications are presented in Table 3. In specification 2, prescriptions dispensed between July 2009

Table 3: Marginal effects multiplied by 100 for specifications 1-4.

\begin{tabular}{lcccc}
\hline & 1. Baseline & 2. No window & 3. LS is presc. & 4. PI is presc. \\
\hline Reform & $-11.34^{\star \star \star}$ & $-6.28^{\star \star \star}$ & $-11.64^{\star \star \star}$ & $-11.84^{\star \star \star}$ \\
March2010 & $(3.11)$ & $(1.42)$ & $(4.50)$ & $(4.50)$ \\
& & $-5.04^{\star \star}$ & & \\
A. Farmaci AB & $(2.23)$ & & \\
& $-21.31^{\star \star \star}$ & $-21.04^{\star \star \star}$ & $-17.60^{\star \star \star}$ & $-29.02^{\star \star \star}$ \\
Apotek Hjärtat & $(1.27)$ & $(1.14)$ & $(0.99)$ & $(4.03)$ \\
& $5.74^{\star \star \star}$ & $4.85^{\star \star \star}$ & $6.31^{\star \star \star}$ & $4.02^{\star \star \star}$ \\
Apoteksgruppen & $(1.37)$ & $(1.27)$ & $(1.66)$ & $(0.79)$ \\
& $7.81^{\star \star \star}$ & $6.63^{\star \star \star}$ & $6.75^{\star \star \star}$ & $10.06^{\star \star \star}$ \\
Bramsäter & $(2.01)$ & $(1.67)$ & $(2.21)$ & $(1.85)$ \\
& 2.23 & 1.57 & $-3.60^{\star}$ & $8.25^{\star \star \star}$ \\
DocMorris & $(1.36)$ & $(1.42)$ & $(1.83)$ & $(1.92)$ \\
Kronans Drogh. & $6.94^{\star \star \star}$ & $5.62^{\star \star \star}$ & $4.76^{\star \star \star}$ & $10.22^{\star \star \star}$ \\
& $(1.49)$ & $(1.49)$ & $(1.73)$ & $(1.03)$ \\
& $-1.98^{\star \star \star}$ & $-2.06^{\star \star \star}$ & $-1.85^{\star \star \star}$ & -0.49 \\
& $(0.58)$ & $(0.52)$ & $(0.70)$ & $(0.78)$ \\
\hline
\end{tabular}


Table 3: (Continued)

\begin{tabular}{|c|c|c|c|c|}
\hline & 1. Baseline & 2. No window & 3. LS is presc. & 4. $P I$ is presc. \\
\hline Malå private & $\begin{array}{l}7.44^{\star \star \star} \\
(1.49)\end{array}$ & $\begin{array}{l}7.41^{\star \star \star} \\
(1.49)\end{array}$ & $\begin{array}{l}6.44^{\star \star \star} \\
(1.63)\end{array}$ & $\begin{array}{l}9.00^{\star \star \star \star} \\
(1.68)\end{array}$ \\
\hline Norsjö private & $\begin{array}{l}18.48^{\star \star \star} \\
(1.59)\end{array}$ & $\begin{array}{l}18.13^{\star \star \star} \\
(1.59)\end{array}$ & $\begin{array}{l}15.50^{\star \star \star} \\
(1.77)\end{array}$ & $\begin{array}{l}17.09^{\star \star \star} \\
(1.38)\end{array}$ \\
\hline Others & $\begin{array}{l}-2.32 \\
(2.38)\end{array}$ & $\begin{array}{l}-3.35 \\
(2.33)\end{array}$ & $\begin{array}{l}-1.73 \\
(2.47)\end{array}$ & $\begin{array}{l}-1.46 \\
(3.03)\end{array}$ \\
\hline Euro & $\begin{array}{l}-6.18^{\star \star \star} \\
(1.07)\end{array}$ & $\begin{array}{l}-6.13^{\star \star \star} \\
(0.98)\end{array}$ & $\begin{array}{l}-5.78^{\star \star \star} \\
(1.00)\end{array}$ & $\begin{array}{l}-4.66^{\star * \star} \\
(1.39)\end{array}$ \\
\hline $\begin{array}{l}\text { Time.mult. with } \\
10,000 \text { instead of } 100\end{array}$ & $\begin{array}{l}-0.09 \\
(0.27)\end{array}$ & $\begin{array}{l}-0.06 \\
(0.25)\end{array}$ & $\begin{array}{l}-0.18 \\
(0.25)\end{array}$ & $\begin{array}{l}-0.38 \\
(0.37)\end{array}$ \\
\hline PI_presc & $\begin{array}{l}24.54^{\star \star \star} \\
(1.38)\end{array}$ & $\begin{array}{l}25.64^{\star \star \star} \\
(1.21)\end{array}$ & & \\
\hline NotMD & $\begin{array}{l}-3.62^{\star \star \star} \\
(0.70)\end{array}$ & $\begin{array}{l}-3.72^{\star \star \star} \\
(0.66)\end{array}$ & $\begin{array}{l}-1.12 \\
(0.94)\end{array}$ & $\begin{array}{l}-3.23^{\star \star \star} \\
(0.76)\end{array}$ \\
\hline InNmpi_drug & $\begin{array}{l}9.05^{\star \star \star} \\
(0.92)\end{array}$ & $\begin{array}{l}9.23^{\star \star \star} \\
(0.81)\end{array}$ & $\begin{array}{l}8.89^{\star \star \star} \\
(0.73)\end{array}$ & $\begin{array}{r}2.00 \\
(1.63)\end{array}$ \\
\hline Nmpi_drug_tr & $\begin{array}{l}3.81^{\star \star \star} \\
(1.46)\end{array}$ & $\begin{array}{l}4.02^{\star \star \star} \\
(1.20)\end{array}$ & $\begin{array}{r}2.24 \\
(1.64)\end{array}$ & $\begin{array}{l}9.03^{\star \star \star} \\
(1.81)\end{array}$ \\
\hline InNmpi_subs & $\begin{array}{r}1.97 \\
(1.28)\end{array}$ & $\begin{array}{r}1.34 \\
(1.17)\end{array}$ & $\begin{array}{l}3.03^{\star \star} \\
(1.23)\end{array}$ & $\begin{array}{l}-7.71^{\star \star \star *} \\
(2.25)\end{array}$ \\
\hline Nmpi_subs_tr & $\begin{array}{r}3.51 \\
(3.50)\end{array}$ & $\begin{array}{r}3.97 \\
(3.16)\end{array}$ & $\begin{array}{r}3.03 \\
(3.47)\end{array}$ & $\begin{array}{l}5.94^{\star} \\
(3.01)\end{array}$ \\
\hline Child $^{\#}$ & $\begin{array}{l}-3.01^{\star \star \star} \\
(0.72)\end{array}$ & $\begin{array}{l}-2.37^{\star \star \star} \\
(0.75)\end{array}$ & $\begin{array}{l}-3.08^{\star \star \star} \\
(0.69)\end{array}$ & $\begin{array}{l}-3.05^{\star \star \star} \\
(0.99)\end{array}$ \\
\hline $\begin{array}{l}\text { Age }^{\# \#} . \text { mult. with } \\
10,000 \text { instead of } 100\end{array}$ & $\begin{array}{l}0.41^{\star \star \star} \\
(0.51)\end{array}$ & $\begin{array}{l}-0.03^{\star \star \star} \\
(0.47)\end{array}$ & $\begin{array}{l}-0.56^{\star \star \star} \\
(0.58)\end{array}$ & $\begin{array}{r}3.48 \\
(0.80)\end{array}$ \\
\hline Women & $\begin{array}{l}-0.54^{\star \star \star} \\
(0.13)\end{array}$ & $\begin{array}{l}-0.51^{\star \star \star} \\
(0.12)\end{array}$ & $\begin{array}{l}-0.78^{\star \star \star} \\
(0.15)\end{array}$ & $\begin{array}{l}-0.00 \\
(0.24)\end{array}$ \\
\hline Total reform effect & $\begin{array}{l}-10.53^{\star \star \star} \\
(2.77)\end{array}$ & $\begin{array}{l}-10.79^{\star \star \star} \\
(2.73)\end{array}$ & $\begin{array}{l}-9.69^{\star \star \star} \\
(2.44)\end{array}$ & $\begin{array}{c}-10.85^{\star \star} \\
(4.48)\end{array}$ \\
\hline Number of obs. & 575,413 & 662,684 & 421,204 & 149,485 \\
\hline Pseudo- $R^{2}$ & 0.4860 & 0.4810 & 0.4500 & 0.3630 \\
\hline
\end{tabular}

Note: Dependent variable: PI. The asterisks ***, ** and * denote significance of the coefficient estimates at the $1 \%, 5 \%$, and $10 \%$ levels. ${ }^{\#}$ Child is evaluated at the mean age for children, which is 11.3 years. ${ }^{\# \#}$ The coefficient estimates for Age are positive and those for $\mathrm{Age}^{2}$ are negative, and both are significant at the $1 \%$ level in specifications 1-3 but not at all significant in specification 4. The marginal effects for Age for specifications 1-3 reflect that the total positive effect of age among the young are of about the same importance as the total negative effect of age among the old. All specifications include controls for calendar months and municipality of residents of the consumer as well as drug-specific fixed effects. 
and March 2010 are included, as well as the indicator variable March2010. In specifications 3 and 4, the populations are restricted to prescriptions of only locally sourced and only parallel imported products, respectively. Key results from other specifications used for robustness analyses are presented and discussed in Appendix C.

The results are presented in terms of average marginal effects and their average standard errors, both multiplied by 100 , as well as asterisks indicating the significance of the coefficient estimates. ${ }^{14}$ For specification 1, estimates for calendar month and municipalities are reported in Table 5 in Appendix A. Corresponding estimates for other specifications as well as parameter estimates for the drug-specific fixed effects are available from the author upon request.

The estimation results for Reform (top of Table 3) show the reform effect for the government-owned Apoteket $\mathrm{AB}$, while the estimates for the nine pharmacy categories (Apoteksgruppen-Others) show how the reform effects for these nine categories differ from that of Apoteket AB. Total reform effect (bottom of the table) is the weighted average of the reform effects over all pharmacy categories, using their market shares after March 2010 as weights (see Table 2).

The results for specification 1 show that the reform reduced the market shares for parallel imports at pharmacies owed by Apoteket AB by 11.3 percentage points. The reform effect is about 2 percentage points larger in absolute size for Kronans Droghandel, while it is 5-6 percentage points smaller for Apoteket Hjärtat. The point estimates for the total reform effect over all pharmacy chains is -10.5 percentage points. As shown in Appendix $C$, these results are quite robust; for example, the estimated total reform effects presented in Table 7 are all between -13 and -8 percentage points. Thus, the results support the main hypothesis that the reform has reduced the market share for parallel imports. The reduction is quite large considering that the predicted market share for parallel imports if the reform had not taken place was $42 \%$ according to specification 1.

The estimates for the nine pharmacy categories reveal that there are significant differences across pharmacies. Except the private pharmacy in Norsjö, all pharmacy categories are, according to the point estimates, less likely to sell parallel imports than Apoteket $\mathrm{AB}$ would have been without the reform, but the differences are not significant for Apoteksgruppen, DocMorris and Malå private. The estimate for Apoteket Farmaci $A B$ is likely affected by selection, since this company only operates hospital pharmacies; the large negative estimate for this group can reflect that consumers who buy drugs in connection to hospital visits

14 Marginal effect and standard errors are calculated using the command margins in Stata SE 11.1, where the delta method is used to estimate the standard errors. 
are less inclined to buy parallel imported products. For the other pharmacy categories, the drug-specific fixed effects and the demographic variables, including the municipality dummies, likely control for most of the selection of consumers.

Specification 2 reveals that the full effect of the reform did not come in July 2009. Instead, the results of specification 2 suggest that about half the estimated reform effect came around July 2009, while the rest came later. Results presented in Table 8 in Appendix $C$ indicate that pharmacies might also have started to adjust to the new rules before July 2009.

The results of specifications 3 and 4 show that the reform effects are of similar absolute size irrespective of whether the prescription is for a locally sourced or a parallel imported product. On the other hand, in relative terms, the reform effect is much larger for prescription of locally sourced products since the predicted market share for parallel imports in this subpopulation if the reform had not taken place is $29 \%$, while it is $83 \%$ for prescriptions for parallel imports.

Looking on the results for the control variables, we see, as expected, that the market share for parallel imports is significantly reduced by a depreciation of the Swedish Krona against the Euro. There is, however, no significant time trend. Consumers are far more likely to buy a parallel import if a parallel imported product is prescribed, which is consistent with the result of Granlund and Rudholm (2012), showing that what the physician has written on the prescription has a significant effect on consumers' choices between medically equivalent pharmaceuticals.

If the prescriber is not a medical doctor, this reduces the likeliness that a parallel import is bought. Specifications 2 and 3 suggest that this is primarily caused by the effect NotMD has when parallel imports are prescribed. The estimates for the four variables controlling for the number of months parallel imported products have been available are consistent with the results of Mott and Cline (2002) and Ching (2010), which showed that the time a product of a drug has been available has a positive effect on the probability that it is bought. The only exception is the negative estimate for lnNmpi_subs in specification 4.

The coefficient estimates (not reported) for Age and $A g e^{2}$ from specification 1 reveal that age, up to an age of 62 , has a positive influence on the probability that a parallel import is bought. For higher ages, the effect is reversed. The estimates for Child show that children are even less likely to get a parallel imported product than what is predicted by their young age according to the estimates for Age and Age ${ }^{2}$. Women are, ceteris paribus, less likely to buy a parallel imported product, and specifications 3 and 4 suggest that this is explained by that women are less inclined to switch product when a locally sourced product is prescribed. 
The descriptive statistics in Figure 1 show that the market share for parallel imported products has increased considerably after the reform: from $25 \%$ in June 2009 (the last month before the reform) to 46\% in December 2011 (the last month in the study period). That the estimated total reform effect still is significantly negative is mainly explained by the depreciation of the Euro against the Swedish Krona: Euro was reduced from nearly 11 in June 2009 to 9 in December 2011. Simulations based on specification 1 suggest that this should have increased the market share for parallel imports by 13 percentage points. Similarly, the increases in the variables lnNmpi_drug, Nmpi_drug_tr, lnNmpi_subs and Nmpi_subs_tr are predicted to have increased the market share by 10 percentage points, of which the increase in lnNmpi_drug accounts for 8 percentage points. Other important control variables explaining the increase in the market share for parallel imports between June 2009 and December 2012 is the calendar month dummies (5 percentage points) and PI_presc (3 percentage points). ${ }^{15}$

\subsection{The Probability That Consumers Can Choose a Cheaper Parallel Imported Product and the Probability That They Still Choose a Locally Sourced Product}

A second hypothesis is that the pharmacy reform has reduced the probability that pharmacies offer consumers to buy cheaper parallel imported products instead of locally sourced ones. This hypothesis is based on the theoretical prediction that pharmacies, because of the reform, will want to have higher generalized prices on parallel imports than on locally sourced products. Higher generalized prices can be accomplished by making parallel traders increase their list prices and by not keeping parallel imports in stock.

The second hypothesis is tested by estimating the probability of Choice as a function of the same explanatory variables as in specification 1, and the results are presented in Table 4. The hypothesis is tested separately depending on whether the prescriptions are for a locally sourced product (specification 5) or for parallel imported products (specification 6).

A related question is, whether the reform has made pharmacies more likely to convince consumers to buy locally sourced products instead of cheaper

15 If I exclude the most important control variable, i.e. the Euro, and neither include the exchange rates between SEK and the other major currencies within the European Economic Area, the estimated total reform effect becomes insignificantly different from zero. On the other hand, excluding the four Nmpi variables reduces the reform effect by less than a half percentage point, since Time then works as a proxy for the Nmpi variables. 
Table 4: Marginal effects multiplied by 100 for specifications 5-9.

\begin{tabular}{|c|c|c|c|c|}
\hline & 5 Choice & 6 Choice & 7 Demand LS & 8 Demand LS \\
\hline & LS is presc. & $P I$ is presc. & LS is presc. & $P I$ is presc. \\
\hline Reform & $\begin{array}{l}-10.10^{\star \star \star} \\
(3.46)\end{array}$ & $\begin{array}{l}-3.58 \\
(4.40)\end{array}$ & $\begin{array}{r}0.81 \\
(1.87)\end{array}$ & $\begin{array}{l}3.84^{\star \star \star} \\
(1.35)\end{array}$ \\
\hline A. Farmaci $A B$ & $\begin{array}{l}-21.84^{\star \star \star} \\
(1.07)\end{array}$ & $\begin{array}{l}-34.40^{* \star *} \\
(3.98)\end{array}$ & $\begin{array}{l}-8.74 \\
(6.25)\end{array}$ & $\begin{array}{l}-1.23 \\
(0.58)\end{array}$ \\
\hline Apotek Hjärtat & $\begin{array}{l}5.59^{\star \star \star} \\
(1.67)\end{array}$ & $\begin{array}{c}1.46^{\star} \\
(0.81)\end{array}$ & $\begin{array}{l}-8.55^{\star \star \star} \\
(0.91)\end{array}$ & $\begin{array}{l}-1.66^{\star \star \star} \\
(0.19)\end{array}$ \\
\hline Apoteksgruppen & $\begin{array}{l}7.73^{\star \star \star} \\
(2.49)\end{array}$ & $\begin{array}{l}12.01^{\star \star \star} \\
(2.58)\end{array}$ & $\begin{array}{l}-7.73^{\star \star \star} \\
(1.43)\end{array}$ & $\begin{array}{l}-0.38 \\
(0.49)\end{array}$ \\
\hline Bramsäter & $\begin{array}{l}-0.11 \\
(1.55)\end{array}$ & $\begin{array}{l}8.56^{\star \star \star} \\
(1.74)\end{array}$ & $\begin{array}{l}4.83^{\star \star} \\
(2.29)\end{array}$ & $\begin{array}{r}0.02 \\
(1.03)\end{array}$ \\
\hline DocMorris & $\begin{array}{l}6.55^{\star \star \star} \\
(1.94)\end{array}$ & $\begin{array}{l}9.01^{\star \star \star} \\
(1.62)\end{array}$ & $\begin{array}{l}-3.75^{\star *} \\
(1.59)\end{array}$ & $\begin{array}{l}-1.94^{\star \star \star} \\
(0.16)\end{array}$ \\
\hline Kronans Drogh. & $\begin{array}{l}-0.47 \\
(1.03)\end{array}$ & $\begin{array}{l}-0.97 \\
(1.00)\end{array}$ & $\begin{array}{r}0.09 \\
(0.64)\end{array}$ & $\begin{array}{r}0.27 \\
(0.33)\end{array}$ \\
\hline Malå private & $\begin{array}{l}10.64^{\star \star \star} \\
(1.94)\end{array}$ & $\begin{array}{l}10.76^{\star \star \star} \\
(2.06)\end{array}$ & $\begin{array}{l}-3.38^{\star *} \\
(1.59)\end{array}$ & $\begin{array}{r}0.30 \\
(1.02)\end{array}$ \\
\hline Norsjö private & $\begin{array}{l}16.77^{\star \star \star} \\
(2.01)\end{array}$ & $\begin{array}{l}19.16^{\star \star \star} \\
(1.58)\end{array}$ & $\begin{array}{l}-11.94^{\star \star *} \\
(0.98)\end{array}$ & $\begin{array}{l}-1.01 \\
(0.65)\end{array}$ \\
\hline Others & $\begin{array}{l}-1.72 \\
(2.70)\end{array}$ & $\begin{array}{l}-2.92 \\
(3.44)\end{array}$ & $\begin{array}{l}-1.65 \\
(0.91)\end{array}$ & $\begin{array}{l}-0.57 \\
(0.90)\end{array}$ \\
\hline Euro & $\begin{array}{l}-5.58^{\star \star \star} \\
(1.14)\end{array}$ & $\begin{array}{l}-2.28^{\star} \\
(1.38)\end{array}$ & $\begin{array}{l}-0.66 \\
(0.48)\end{array}$ & $\begin{array}{r}0.46 \\
(0.31)\end{array}$ \\
\hline $\begin{array}{l}\text { Time.mult. by } \\
10,000 \text { instead of } 100\end{array}$ & $\begin{array}{r}0.13 \\
(0.31)\end{array}$ & $\begin{array}{l}-1.01^{\star * *} \\
(0.37)\end{array}$ & $\begin{array}{l}0.52^{\star \star \star} \\
(0.14)\end{array}$ & $\begin{array}{r}0.05 \\
(0.08)\end{array}$ \\
\hline NotMD & $\begin{array}{l}-0.68 \\
(0.96)\end{array}$ & $\begin{array}{l}-3.08^{\star \star \star} \\
(0.87)\end{array}$ & $\begin{array}{c}4.56^{\star} \\
(2.83)\end{array}$ & $\begin{array}{l}-0.13 \\
(0.34)\end{array}$ \\
\hline InNmpi_drug & $\begin{array}{l}8.44^{* \star *} \\
(0.77)\end{array}$ & $\begin{array}{c}3.30^{\star} \\
(1.76)\end{array}$ & $\begin{array}{l}-3.95^{\star \star \star} \\
(0.75)\end{array}$ & $\begin{array}{l}-0.67 \\
(0.55)\end{array}$ \\
\hline Nmpi_drug_tr & $\begin{array}{l}3.54^{\star \star} \\
(1.63)\end{array}$ & $\begin{array}{l}8.67^{\star \star \star} \\
(1.65)\end{array}$ & $\begin{array}{l}11.38^{\star \star \star} \\
(1.46)\end{array}$ & $\begin{array}{r}0.32 \\
(0.32)\end{array}$ \\
\hline InNmpi_subs & $\begin{array}{l}3.51^{\star \star \star} \\
(1.30)\end{array}$ & $\begin{array}{l}-8.45^{\star \star \star} \\
(2.47)\end{array}$ & $\begin{array}{l}4.92^{\star \star \star} \\
(1.17)\end{array}$ & $\begin{array}{r}0.94 \\
(0.72)\end{array}$ \\
\hline Nmpi_subs_tr & $\begin{array}{r}4.32 \\
(3.86)\end{array}$ & $\begin{array}{l}11.53^{\star \star \star} \\
(3.05)\end{array}$ & $\begin{array}{l}7.47^{\star \star \star \star} \\
(2.78)\end{array}$ & $\begin{array}{l}-0.70 \\
(0.67)\end{array}$ \\
\hline Child $^{\#}$ & $\begin{array}{l}-0.38 \\
(0.60)\end{array}$ & $\begin{array}{r}0.49 \\
(1.00)\end{array}$ & $\begin{array}{l}4.60^{\star *} \\
(2.36)\end{array}$ & $\begin{array}{r}0.50 \\
(0.49)\end{array}$ \\
\hline $\begin{array}{l}\text { Age } \# \# \text {.mult. with } \\
10,000 \text { instead of } 100\end{array}$ & $\begin{array}{l}-0.70^{\star *} \\
(0.54)\end{array}$ & $\begin{array}{r}0.10 \\
(1.00)\end{array}$ & $\begin{array}{l}5.22^{\star \star \star} \\
(1.00)\end{array}$ & $\begin{array}{l}0.35^{\star * *} \\
(0.33)\end{array}$ \\
\hline Women & $\begin{array}{r}0.05 \\
(0.16)\end{array}$ & $\begin{array}{r}0.33 \\
(0.27)\end{array}$ & $\begin{array}{l}3.02^{\star \star *} \\
(0.18)\end{array}$ & $\begin{array}{r}0.05 \\
(0.07)\end{array}$ \\
\hline Total reform effect & $\begin{array}{l}-8.76^{\star \star \star} \\
(2.91)\end{array}$ & $\begin{array}{l}-3.37 \\
(4.38)\end{array}$ & $(1.80)^{-1.45}$ & $\begin{array}{l}3.52^{\star \star \star} \\
(1.31)\end{array}$ \\
\hline Number of obs. & 424,628 & 149,646 & 123,413 & 90,694 \\
\hline Pseudo- $R^{2}$ & 0.4507 & 0.3693 & 0.3421 & 0.2860 \\
\hline
\end{tabular}

Note: Dependent variables: Choice and Demand LS. The asterisks ${ }^{\star \star \star}$, ${ }^{\star *}$ and ${ }^{\star}$ denote significance of the coefficient estimates at the $1 \%, 5 \%$, and $10 \%$ levels. ${ }^{\#}$ Child is evaluated at the mean age for children, which is 11.3 years. ${ }^{\# \#}$ The coefficient estimates for Age are positive and those for $A g e^{2}$ are negative, and both are significant at the $1 \%$ level in specifications 7 and 8 and at the $5 \%$ level in specifications 5 , but they are not significant in specification 6. All specifications include controls for calendar months and municipality of residents of the consumer as well as drug-specific fixed effects. 
alternatives? This is tested by estimating the probability of Demand LS as a function of the same explanatory variables as in specification 1 but only for observation where consumers had a choice. Also this is tested separately depending on whether the prescriptions are for a locally sourced product (specification 7) or for parallel imported products (specification 8).

As predicted by the theoretical model, the results in Table 4 show that the reform has reduced the probability that a consumer who was prescribed a locally sourced product was offered a cheaper parallel imported substitute. On the other hand, for consumers who were prescribed parallel imported products, the reform's negative effect on the probability that they are able to buy parallel imported products that are cheaper than the locally sourced products is not statistically significant. A possible explanation is that the reform mostly has affected the probability that pharmacies keep parallel imported products that are seldom prescribed in stock, since it can create bad will among consumers not to have the product they are prescribed in stock.

Looking at the estimate for Total reform effect from specification 7, we see that consumers across all pharmacies did not become more likely to reject to substitute a prescribed locally sourced product for a cheaper parallel imported alternative. That is, we see no evidence for that the increase in market share for locally sourced product when such products are prescribed is explained by that pharmacies because of the reform are more likely to persuade consumers to buy locally sourced products.

The results from specification 8 show that the reform has increased the probability that consumers who are prescribed parallel imported products pay extra to instead get a locally sourced product. One interpretation is that pharmacy personnel because of the reform have become more likely to tell consumers that they have the right to buy other substitutes than the prescribed product or the cheapest available substitute.

To summarize, the results of specifications 5-8 indicate that pharmacies primarily have reduced the market share for parallel imports by less often offer consumers to buy cheaper parallel imported products. The mechanism suggested by Brekke, Holmås, and Straume (2013) for off-patent drugs in Norway - that pharmacies persuade consumers to buy products that pharmacies have higher margins on, are less important on this market. Table 9 in Appendix $C$ shows that the main results from specifications 5-8 are not sensitive toward excluding all observations where a parallel imported product with unknown relative price is dispensed.

We see that the estimated reform effects from specifications 6 and 8 together only can explain a part of the estimated reform effect from specification 4 (i.e. for 
prescriptions of parallel imported products). The same is true for prescriptions of locally sourced products: the estimated reform effects from specifications 5 and 7 do not explain the entire reform effect according to specification 3, even though the result from specification 5 explains a large part. The main reason is that the reform also has affected the probability that consumers buy a parallel imported product that is not cheaper than the locally sourced product. The data do not reveal if consumers who bought a locally sourced product had the opportunity to buy an equally expensive parallel imported product, which means that it is not possible to analyze the mechanism through which the reform reduced the probability that consumers buy parallel imported products that are not cheaper than their locally sourced alternatives.

The results above are consistent with the theoretical prediction that when pharmacies can negotiate purchase prices, the marginal purchase prices become lower for locally sourced products than for parallel imports. In other words, the producers give larger marginal discounts than given by parallel traders. Another question is if parallel traders at all give discounts. According to the theoretical model, this is expected if the pharmacies' maximum purchase price for parallel imports exceeds $p_{s}+r$. Results presented and discussed in Appendix D indicate that the reform has significantly increased the probability that pharmacies only sell product from one parallel trader for each drug. These results are obtained after controlling for the quantity of parallel imports sold and are consistent with that pharmacies negotiate prices also with parallel traders and, for each drug, only sell the product from the parallel trader who offered them the best deal.

\section{Conclusion}

The theoretical model in this paper shows that negotiations on discounts will lead to a low market share for parallel imports since producers always will be able to underbid the offers of parallel traders. Parallel imports will only be sold to part of the consumers who without costly persuasion by pharmacy personnel would be prepared to pay more for a parallel imported product than for a locally sourced one if both were available at the pharmacy. This might seem surprising since parallel imports in many countries are low-priced alternatives, but it is explained by that parallel traders always have a cost disadvantage relative to producers; in addition to buying products that are initially sold by the producers, parallel traders also have cost for repacking and trading. For interior 
solutions, the market share of parallel imports will be a negative function of their cost disadvantage.

The empirical results show that a reform that allowed discount negotiations, when pharmacies' margins initially were regulated and nearly identical for locally sourced and parallel imported products, reduced the market shares for parallel imports by about 11 percentage points. The results are robust and are obtained using a unique prescription-level dataset that includes consumer, prescriber and pharmaceutical variables. The results agree with Brekke, Holmås, and Straume's (2013) that pharmacies are not perfect agents for consumers and that pharmacy incentives have important effects on the choice between medically equivalent pharmaceuticals.

That producers would give pharmacies discounts and increase their market shares was not expected by the government but should still be welcomed. That the total cost for repacking and trading are reduced when the quantities of parallel imports are reduced, is a pure efficiency gain. Increased margins for pharmacies can benefit consumers by making pharmacies more willing to increase their services to compete for consumers. Alternatively, the government can try to keep the average margins constant so that consumers instead benefit from lower maximum retail prices. For fixed maximum prices, producers' revenues are increased for each unit that is sold directly to wholesalers in Sweden instead of through parallel traders. The government could transfer this increased producer surplus to consumers by lowering the maximum wholesale and retail prices.

The paper complement Brekke, Holmås, and Straume (2013) by studying the effects of a reform that changed pharmacies' incentives, by studying on-patent drugs instead off off-patent drugs and by analyzing which measures pharmacies take to affect the market shares. The results show that the most important mechanism is that the reform has reduced the probability that consumers are offered a cheaper parallel imported alternative. There are no indications that pharmacy personnel have reduced the market share for parallel imports by persuading consumers not to buy such products when locally sourced products are prescribed. However, the results suggest that a part of the reduction is explained by that pharmacies have become more likely to inform consumers who are prescribed parallel imported pharmaceuticals about the possibility to buy other substitutes than the prescribed product or the cheapest available substitute. The role of pharmacies has so far been nearly neglected, and to better understand the pharmaceutical market, more research effort should be devoted to study pharmacies' behavior. 


\section{Appendix A: Month and Municipality Effects}

Table 5: Additional estimation results for specification 1.

\begin{tabular}{|c|c|c|c|}
\hline \multirow{2}{*}{$\frac{\text { Month }}{\text { February }}$} & \multicolumn{3}{|c|}{ Municipality } \\
\hline & $\begin{array}{l}-0.65 \\
(1.45)\end{array}$ & Bjurholm & $\begin{array}{r}0.81 \\
(0.72)\end{array}$ \\
\hline March & $\begin{array}{r}0.58 \\
(1.65)\end{array}$ & Dorotea & $\begin{array}{l}-3.30^{\star \star \star} \\
(0.82)\end{array}$ \\
\hline April & $\begin{array}{l}-1.01 . \\
(1.84)\end{array}$ & Lycksele & $\begin{array}{l}-3.75^{\star \star \star} \\
(0.56)\end{array}$ \\
\hline May & $\begin{array}{l}-3.39^{\star} \\
(1.76)\end{array}$ & Malå & $\begin{array}{l}-0.58 \\
(0.62)\end{array}$ \\
\hline June & $\begin{array}{l}-3.54^{\star \star} \\
(1.41)\end{array}$ & Nordmaling & $\begin{array}{l}-1.14^{\star \star} \\
(0.53)\end{array}$ \\
\hline July & $\begin{array}{l}-2.60^{\star} \\
(1.54)\end{array}$ & Norsjö & $\begin{array}{l}-5.49^{\star \star \star} \\
(0.75)\end{array}$ \\
\hline August & $\begin{array}{l}-2.28 \\
(1.85)\end{array}$ & Robertsfors & $\begin{array}{l}1.28^{\star \star \star} \\
(0.43)\end{array}$ \\
\hline September & $\begin{array}{l}-1.67 \\
(1.83)\end{array}$ & Skellefteå & $\begin{array}{l}-0.02 \\
(0.24)\end{array}$ \\
\hline October & $\begin{array}{l}-1.65 \\
(1.93)\end{array}$ & Sorsele & $\begin{array}{l}-0.28 \\
(0.85)\end{array}$ \\
\hline November & $\begin{array}{l}-0.80 \\
(1.83)\end{array}$ & Storuman & $\begin{array}{l}-2.27^{\star \star \star} \\
(0.79)\end{array}$ \\
\hline December & $\begin{array}{r}0.82 \\
(2.81)\end{array}$ & Vilhelmina & $\begin{array}{l}-5.67^{\star \star \star} \\
(0.80)\end{array}$ \\
\hline & & Vindeln & $\begin{array}{l}1.86^{\star \star \star *} \\
(0.55)\end{array}$ \\
\hline & & Vännäs & $\begin{array}{l}3.00^{\star \star \star} \\
(0.43)\end{array}$ \\
\hline & & Åsele & $\begin{array}{l}-3.14^{\star \star \star} \\
(0.71)\end{array}$ \\
\hline
\end{tabular}

Note: Dependent variable: $P I$. The asterisks ${ }^{\star \star \star}$, ** and * denote significance of the coefficient estimates at the $1 \%, 5 \%$, and $10 \%$ levels. January and Umeå are the omitted categories.

\section{Appendix B: Pharmacies in the County of Västerbotten}

During the study period, six chains operated pharmacies in the county of Västerbotten. Apoteket $\mathrm{AB}$ had over 40 pharmacies before the sellout and 11-12 pharmacies after, and the affiliated government-owned chain Apoteket Farmaci AB 
operated two hospital pharmacies after the reform. Apotek Hjärtat and Kronans Droghandel took over their 11 and 18 pharmacies in February 2010, while DocMorris opened its only pharmacy in Västerbotten in October 2010. Two pharmacies were during a period owned by the chain Apoteksgruppen but were taken over by private owners in October 2010 (the one located in Malå, see Map 1 and Table 5 in Appendix A) and March 2011 (the one located in Norsjö). In addition, Bramsäter Medicalshop AB opened one pharmacy in May 2011.

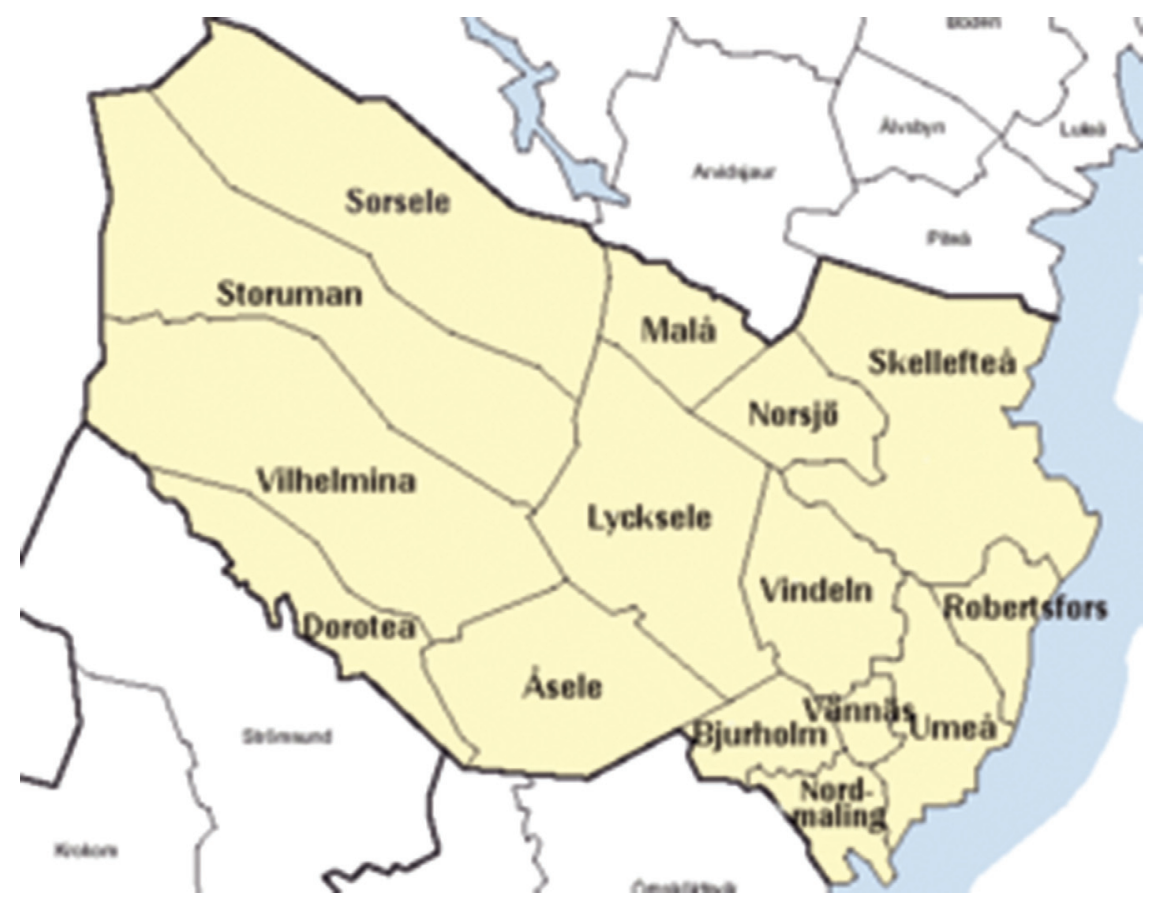

Map 1: Municipalities in the county of Västerbotten, Sweden.

The county of Västerbotten (population 259,286; December 31, 2010) consists of 15 municipalities. The largest cities are Umeå (population 79,594), Skellefteå (population 32,775), and Lycksele (population 8,513). Besides Umeå and Skellefteå, the county is sparsely populated with a population density of less than 5 residents per square kilometer. In Umeå and Skellefteå, there have been several competing pharmacy chains since the beginning of the reform. When DocMorris opened its pharmacy in October 2010, Lycksele got its second pharmacy chain, but in the other 12 municipalities only 1 pharmacy chain was present. 
Table 6: Pharmacy chains active in Västerbotten, March 2010-December 2011.

\begin{tabular}{ll}
\hline Municipality & Pharmacy chain and number of pharmacies \\
\hline Bjurholm & AH 1 \\
Dorotea & KD 1 \\
Lycksele & AH 1 , DocMorris $0 / 1$ \\
Malå & AG/Malå Private 1 \\
Nordmaling & AH 1 \\
Norsjö & AG/Norsjö Private 1 \\
Robertsfors & Apoteket AB 1 \\
Skellefteå & AH 5, KD 3, Apoteket AB 5, Apoteket Pharm. AB 1, Bramsäter 0/1 \\
Sorsele & KD 1 \\
Storuman & KD 2 \\
Umeå & AH 3, KD 7, Apoteket AB 4/5, Apoteket Pharm. AB 1 \\
Vilhelmina & KD 1 \\
Vindeln & KD 1 \\
Vännäs & KD 1 \\
Åsele & KD 1 \\
\hline
\end{tabular}

Note: KD, Kronans Droghandel; AG, Apoteksgruppen; AH, Apoteket Hjärtat. 0/1 and 4/5 indicate that there was a change in the number over time.

\section{Appendix C: Robustness Analyses}

Table 7 presents key results from estimations that differ from the baseline specification by: not controlling for PI_presc (specification A1); also controlling for the other seven major currencies of the European Economic Area (specification A2); lagging Euro 2 months (specification A3); using probit instead of logit (specification A4) and clustering on year instead of months (specification A5). To facilitate comparison, the key result of specification 1 is also presented in Table 7 .

The largest absolute total reform effect on the baseline population is obtained using specification A1, which does not control for whether the prescriptions are for parallel imports or not. This suggests that the probability that a parallel imported product is prescribed is negatively associated with the reform after controlling for the other explanatory variables, which is also supported by a logit estimation with PI_presc as dependent variable. One explanation to this association can be a causal one: that some products were stopped being parallel imported to Sweden because of the reform and, therefore, also was taken away from the prescription lists. However, the data reveal that products can be prescribed even when they are no longer sold. If the bulk part of the association between PI_presc and the reform still is a causal effect of the reform, despite that physicians did not have any incentive do change the share of prescriptions that 


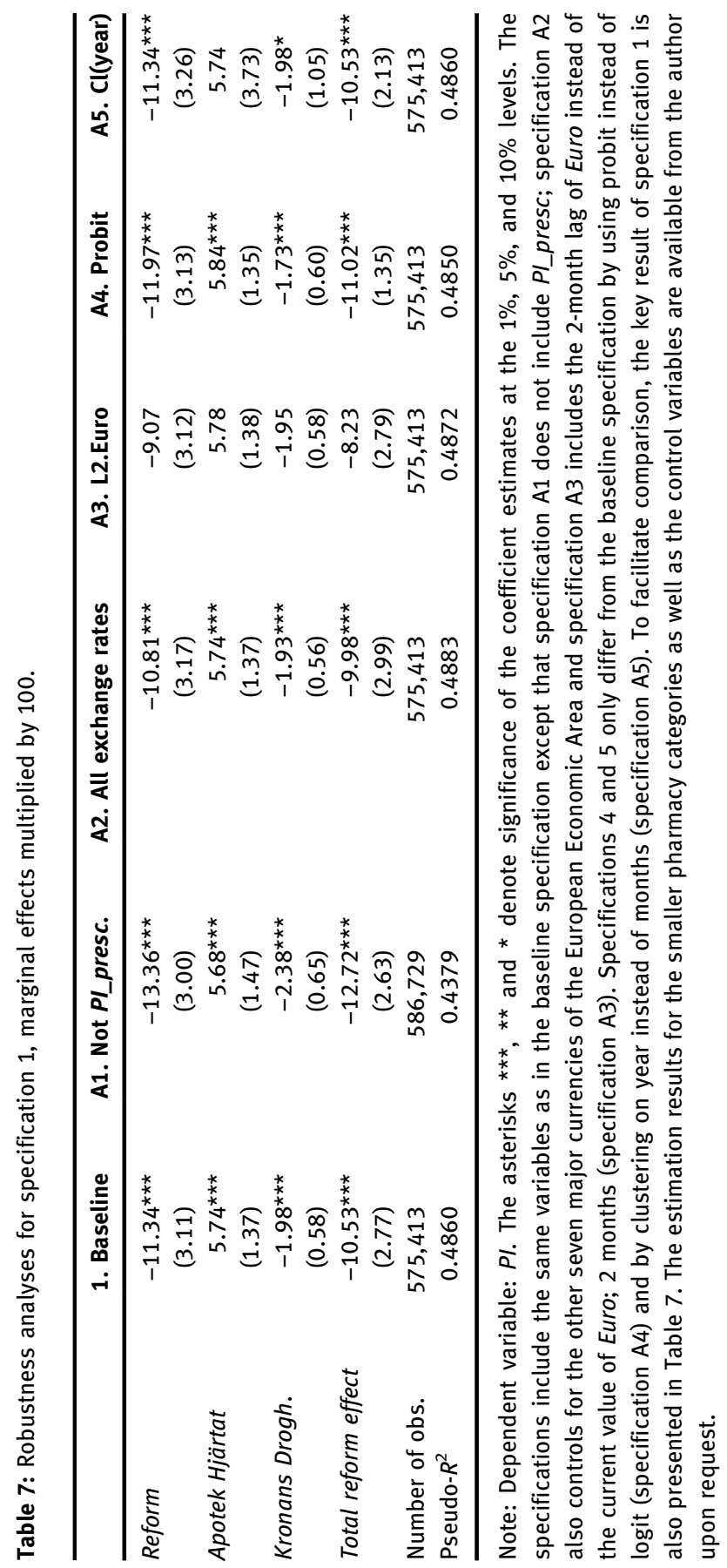


was for parallel imports due to the reform, the result from specification A1 is a better estimate of the total reform effect than that from specification 1, since the estimate from specification 1 does not capture the effect that goes through PI_presc. Without having information about other factors affecting physicians' prescription, one cannot, however, conclude to which extent the reform has caused a reduction in the share of prescriptions for parallel imports. Specification A1 is estimated also using observations lacking data on PI_presc, but excluding these extra observations only has minor effects on the results.

The results from specification A2 show that controlling for the exchange rates between the Swedish Krona and currencies of the Czech Republic, Denmark, Hungary, Iceland, Norway, Poland, Romania and the United Kingdom only reduces the estimated reform effect by a half percentage points in absolute value. The smallest estimate of total reform effect in absolute value is obtained when the second lag of Euro is used instead of the current exchange rate. Twomonth lag gives the highest pseudo- $R^{2}$ of the lag lengths tested, and it also gives a higher pseudo- $R^{2}$ value than specification 1. A 2-month lag can make sense if parallel traders do not have access to good forecast of the exchange rate and if it takes around 2 months to repackage and deliver products bought in the low-price countries. High correlation between different exchange rates and the possibility that the exchange rates also correlates with unmeasured variables, such as the consumers' perception of their own future income (the Swedish currency tends to depreciate when economic uncertainty increases), which might affect their choices, makes it hard to conclude which way is optimal to control for the exchange rates. To study this more carefully, one would preferably use data covering parallel imports to many countries. However, specifications 1, A2 and A3 as well as others not reported indicate that the main result is quite stable against changes in how exchange rates are accounted for.

Specification A4 reveals that the estimated reform effect is about a half percentage point larger in absolute value when probit is used instead of logit. Comparing specifications 1 and A5 reveals that different standard errors are affected in different directions by the choice of clustering unit. Clustering on year gives the largest standard errors for Apotek Hjärtat of the clustering units tested, but the standard error for the total reform effect is smaller than when clustering on months. In two specifications that are not presented in tables, I have clustered on drug groups and the reform indicator, respectively. Also in both these specifications, the total reform effects are significant at the $1 \%$ level.

The four specifications presented in Table 8 are used to investigate whether the estimated reform effects are sensitive to the choice of time periods and if pharmacies started to adjust to the reform before July 2009. In specifications A6 and A7, the same window as in the baseline specification is used, i.e. 
Table 8: Marginal effects multiplied by 100 for specifications $10-13$, which differ in time periods covered.

\begin{tabular}{lcccc}
\hline & A6. From 2008 & A7. To July 2011 & A8. Law, April 29 & A9. Bill, Feb. 19 \\
\hline Reform & $-11.79^{\star \star \star}$ & $-7.35^{\star \star}$ & $-12.91^{\star \star \star}$ & $-15.16^{\star \star \star}$ \\
& $(4.06)$ & $(3.04)$ & $(3.08)$ & $(2.47)$ \\
Apotek Hjärtat & $6.03^{\star \star \star}$ & $3.92^{\star \star \star}$ & $5.79^{\star \star \star}$ & $5.89^{\star \star \star}$ \\
& $(1.46)$ & $(1.31)$ & $(1.34)$ & $(1.34)$ \\
Kronans Drogh. & $-2.23^{\star \star \star}$ & $-1.97^{\star \star \star}$ & $-1.89^{\star \star \star}$ & $-1.84^{\star \star \star}$ \\
& $(0.62)$ & $(0.72)$ & $(0.56)$ & $(0.55)$ \\
Total reform effect & $-11.00^{\star \star \star}$ & $-6.98^{\star \star \star}$ & $-12.04^{\star \star \star}$ & $-14.23^{\star \star \star}$ \\
& $(3.71)$ & $(2.59)$ & $(2.78)$ & $(2.22)$ \\
Number of obs. & 424,585 & 496,371 & 550,983 & 514,531 \\
Pseudo- $R^{2}$ & 0.4443 & 0.4800 & 0.4919 & 0.4933 \\
\hline
\end{tabular}

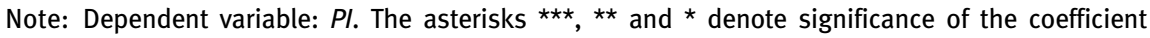
estimates at the $1 \%, 5 \%$, and $10 \%$ levels. The specifications include the same variables as in the baseline specification; estimation results for the smaller pharmacy categories as well as the control variables are available from the author upon request. The specifications only differ from the baseline specification by not including observations from 2007 (specification A6); July 2011-December 2011 (specification A7); April 29, 2009-June 30, 2009 (specification A8) and February 19, 2009-June 30, 2009 (specification A9).

prescriptions dispensed in July 2009-February 2010 are excluded, but in addition observations from 2007 are excluded in specification A6, and in specification A7, observations from the last 6 months of the baseline study period are excluded. I chose not to exclude all 12 months of 2011, since this would only leave 10 months after the reform for this study.

Since pharmacies knew about the reform before it came into effect, they could have started to adjust to the new rules before July 2009. If this was the case, we would expect to obtain larger estimates of the reform effect if the estimations were performed excluding observations from the months directly before the reform. To study the importance of this possibility, prescriptions dispensed from April 29, 2009, when the law regarding the pharmacy reform was passed by parliament, until March 2010 are excluded from specification A8, and prescriptions dispensed from February 19, 2009, when the bill was presented to parliament, until March 2010 are excluded from specification A9.

Comparing the estimates from specifications A6 and 1 shows that excluding 2007 has only minor effects on the key results. Excluding the last 6 months of 2011, however, reduces the estimated total reform effect by 3.5 percentage points or about one-and-a-third standard errors. This might indicate that the reform effect continued to increase in absolute value during the study period and hence 
that the long-term effect might be an even larger reduction in the market share for parallel imported products than the 11 percentage points predicted by the baseline specification. The results from specifications A8 and A9 reveal that the estimated reform effect becomes larger in absolute value the longer time period before the reform that is excluded. This is consistent with the idea that Apoteket $\mathrm{AB}$ could have started to adjust to the rules before they came into effect.

Table 9 shows that the main results from specifications 5-8 reported in Table 4 are not sensitive toward excluding all observations where a parallel imported product with unknown relative price is dispensed.

Table 9: Robustness analysis for specifications 5-8, marginal effects multiplied by 100 .

\begin{tabular}{lcccc}
\hline & A10 Choice & A11 Choice & A12 Demand LS & A13 Demand LS \\
\cline { 2 - 5 } & LS is presc. & PI is presc. & LS is presc. & PI is presc. \\
\hline Reform & $-10.54^{\star \star \star}$ & -7.44 & 0.33 & $5.75^{\star \star \star}$ \\
Apotek Hjärtat & $(2.99)$ & $(5.14)$ & $(1.98)$ & $(2.00)$ \\
& $5.30^{\star \star \star}$ & 0.36 & $-9.30^{\star \star \star}$ & $-2.31^{\star \star \star}$ \\
Kronans Drogh. & $(1.44)$ & $(0.88)$ & $(0.99)$ & $(0.27)$ \\
& -0.07 & -1.02 & -0.08 & 0.23 \\
Total reform effect & $(0.91)$ & $(1.13)$ & $(0.67)$ & $(0.47)$ \\
& $-9.14^{\star \star \star}$ & -7.59 & -2.19 & $5.24^{\star \star \star}$ \\
Number of obs. & $(2.50)$ & $(5.05)$ & $(1.92)$ & $(1.97)$ \\
Pseudo- $R^{2}$ & 404,686 & 128,209 & 107,379 & 74,729 \\
\hline
\end{tabular}

Note: Dependent variables: The asterisks ***, ${ }^{* \star}$ and ${ }^{\star}$ denote significance of the coefficient estimates at the $1 \%, 5 \%$, and $10 \%$ levels. Choice and Demand LS. The specifications include the same variables as in the baseline specification; estimation results for the smaller pharmacy categories as well as the control variables are available from the author upon request.

\section{Appendix D: Share of Parallel Imports Sold by the Parallel Trader with Largest Market Share in the Municipality}

If all parallel traders have identical cost functions, it is possible that they would all give the same discounts and that all would retain the same share of the sales of parallel imports. However, if some parallel traders are able to offer a pharmacy lower purchase prices than its competitors, one would expect that the reform has increased the probability that a pharmacy only sell parallel imports from the parallel trader that offers the lowest price for each drug. For a given size of a pharmacy chain, one would then expect the reform to have increased the probability that a pharmacy chain only 
sells parallel imports from one parallel trader for each drug. But, since the reform increased the number of chains, it is better to look at sales of individual pharmacies instead of sales of pharmacy chains.

Except for the three pharmacy categories that include only one pharmacy each after the reform, the data do not identify single pharmacies. However, 11 of the 15 municipalities within the county only had only 1 pharmacy during the entire study period. For the subpopulation consisting of prescriptions bought by residents of these 11 municipalities, the municipality of residence identifies single pharmacies except for that some consumers do not buy pharmaceuticals at their home pharmacy.

The data show that $88.82 \%$ and $80.78 \%$ of the prescriptions bought by residents of Malå and Norsjö after that the pharmacies in these municipalities became privately owned were bought in Malå and Norsjö, respectively. Considering the geographical distances, one might suspect that these figures are approximately representative for all 11 municipalities with only one pharmacy. This implies that if one parallel trader captures $80-90 \%$ of the sales of parallel imports of one drug to residents of one of these municipalities, it is consistent with that the parallel trader gets $100 \%$ of sales of parallel imports of that drug at the pharmacy in the municipality.

To investigate whether the reform has affected this probability, I estimate

$$
\begin{aligned}
& \operatorname{Pr}\left(\text { ShareX }_{P D R}=1\right) \\
& =F\left(\beta_{1} \text { Reform }_{P}+\beta_{2} \text { Trend }_{P}+\beta_{3} \text { PresC }_{P D R}+\beta_{4} \text { Presc }_{P D R}^{2}+\sum_{m=2}^{12} \theta_{m} \text { CMonth }_{m P}\right. \\
& \left.\quad+\sum_{r=2}^{11} \rho_{r} \text { Mun }_{r R}+\sum_{d=2}^{218} \alpha_{d} \text { Drug }_{d D}+\varepsilon_{i}\right)
\end{aligned}
$$

where the dependent variable takes the value 1 if the parallel trader with largest market share within a period-drug-municipality observation has a market share that exceeds $75 \%, 80 \%, 85 \%, 90 \%$ or $95 \%$, respectively, and where the subindexes $P, D$ and $R$ refer to the period, drug and the municipality of residence of the consumer. The market share is defined as the number of prescriptions where parallel imported products delivered by the parallel trader with largest market share within the observation are dispensed, divided by Presc. Presc is the number of prescriptions where parallel imported products are dispensed. The period is chosen to be 1 month since the maximum purchase prices do not change within a month. Trend is the number of months since the start of the study period. Presc ${ }^{2}$ is the square of Presc, and the indicator variables are defined in the Section 4. The population is restricted to the 11 municipalities with only 1 pharmacy during the entire study period, and observations where the number of prescriptions equals one are excluded since the market share in these cases cannot be anything other than one. 
The results in Table 11 indicate that the probability that a pharmacy only buys parallel imported products of a drug from one parallel trader is significantly increased by the reform. The time trend is negative, but even if I do not control for the time trend, the reform effect is still statistically significant from zero at the $1 \%$ level for all five dependent variables, but the point estimates are then 8-11 percentage points smaller. When estimating separately depending on whether the pharmacies in the municipalities after the reform is operated by Kronans Droghandel, Apoteksgruppen, Apoteket Hjärtat or Apoteket AB, I found that the reform effect was significant for all groups.

Table 10 presents the percentage where each dependent variable equals 1 as well as means, standard deviations and minimum and maximum values for Presc and Presc ${ }^{2}$. Table 11 contains estimation results.

Table 10: Descriptive statistics.

\begin{tabular}{lrrr}
\hline Variable & Population & Min. & Max. \\
\hline Share75 & 59.43 & & \\
Share80 & 56.78 & & \\
Share85 & 54.84 & & \\
Share90 & 52.49 & & \\
Share95 & 50.97 & & \\
Presc & $5.14 \pm 4.94$ & 2 & 2,209 \\
Presc $^{2}$ & $50.75 \pm 126.68$ & 4 & \\
\hline
\end{tabular}

Note: The number of observations is 8,743 . For the indicator variables, the percentage belonging to each category is presented, and for continuous variables, means and standard deviations are presented. Variable definitions and data sources are given in the text of this section.

Table 11: Marginal effects multiplied by 100 . Dependent variables: Share $X_{P D R}, X=75,80,85$, 90, 95.

\begin{tabular}{lccccc}
\hline & Share75 $_{P D R}$ & Share80 $_{P D R}$ & Share85 $_{P D R}$ & Share90 $_{P D R}$ & Share95 $_{P D R}$ \\
\hline Reform & $21.24^{\star \star \star}$ & $22.26^{\star \star \star}$ & $22.00^{\star \star \star}$ & $20.77^{\star \star \star}$ & $20.15^{\star \star \star}$ \\
& $(4.83)$ & $(4.88)$ & $(4.81)$ & $(4.73)$ & $(4.71)$ \\
Trend & $-0.27^{\star \star}$ & $-0.31^{\star \star}$ & $-0.33^{\star \star \star}$ & $-0.33^{\star \star \star}$ & $-0.35^{\star \star \star}$ \\
& $(0.12)$ & $(0.12)$ & $(0.12)$ & $(0.12)$ & $(0.12)$ \\
Presc $^{\#}$ & $-1.03^{\star \star \star}$ & $-1.59^{\star \star \star}$ & $-2.28^{\star \star \star}$ & $-3.14^{\star \star \star}$ & $-4.12^{\star \star \star}$ \\
& $(0.33)$ & $(0.35)$ & $(0.35)$ & $(0.33)$ & $(0.29)$ \\
Number of obs. & 8,743 & 8,743 & 8,743 & 8,743 & 8,743 \\
Pseudo- $R^{2}$ & 0.1006 & 0.1078 & 0.1147 & 0.1301 & 0.1524 \\
\hline
\end{tabular}

Note: The asterisks ${ }^{* \star *}$, ${ }^{*}$ and ${ }^{*}$ denote significance of the coefficient estimates at the $1 \%, 5 \%$, and $10 \%$ levels. ${ }^{\#}$ The coefficient estimates for Presc are negative and those for Presc $^{2}$ are positive, and all are significant at $1 \%$ level. All specifications include controls for calendar months and municipality of residence of the consumers as well as drug-specific fixed effects. 
Acknowledgments: The author would like to thank Thomas Aronsson, Douglas Lundin, Andrea Mannberg, two anonymous reviewers and participants at the Fifth Swedish Workshop on Competition Research and at a seminar at Umeå University for helpful comments and suggestions. The author is grateful to Västerbotten County Council and IMS Sweden for providing the datasets and to the Swedish Competition Authority for a research grant that supported the work.

Funding: The Swedish Competition Authority.

\section{References}

Andersson, K., C. Sonesson, M. Petzold, A. Carlsten, and K. Lönnroth. 2005. "What Are the Obstacles to Generic Substitution? An Assessment of the Behaviour of Prescribers, Patients and Pharmacies During the First Year of Generic Substitution in Sweden." Pharmacoepidemiology and Drug Safety 14: 341-8.

Baltagi, B. 2001. Econometric Analysis of Panel Data, 2nd ed. Chichester: John Wiley and Sons LTD.

Brekke, K. R., T. H. Holmås, and O. R. Straume. 2013. "Margins and Market Shares: Pharmacy Incentives for Generic Substitution." European Economic Review 61: 116-31.

Chen, Y., and K. E. Maskus. 2005. "Vertical Pricing and Parallel Imports." Journal of International Trade and Economic Development 14: 1-18.

Ching, A. 2010. "Consumer Learning and Heterogeneity: Dynamics of Demand for Prescription Drugs After Patent Expiration." International Journal of Industrial Organization 28: 619-38.

Coscelli, A. 2000. “The Importance of Doctors' and Patients' Preferences in Prescription Drug Markets." Journal of Industrial Economics 48: 349-69.

Dental- and Pharmaceutical Benefit Agency. 2009. TLVFS 2009:4, Tandvårds- och läkemedelsförmånsverkets föreskrifter och allmänna råd om prissättning av utbytbara läkemedel och utbyte av läkemedel m.m. [Dental- and Pharmaceutical Benefit Agency's regulations and general advices about price setting of exchangeable pharmaceuticals and substitution of pharmaceuticals etc.] (in Swedish). Accessed April 2, 2012, at http://www.tlv.se.

Dental- and Pharmaceutical Benefit Agency. 2012. 2012 års översyn av apotekens handels marginal - en samlad bedömning av ersättningen till apoteksmarknaden [The year 2012 review of the pharmacy trade margin - an overall assessment of the remuneration to the pharmacy market] (in Swedish). Accessed June 12, 2012, at http://www.tlv.se.

Dubé, J. -P., G. Hitsch, and P. Rossi. 2010. "State Dependence and Alternative Explanations for Consumer Inertia." RAND Journal of Economics 41: 417-45.

Ganslandt, M., and K. E. Maskus. 2004. "Parallel Imports and the Pricing of Pharmaceutical Products: Evidence From the European Union.” Journal of Health Economics 23: 1035-57.

Granlund, D. 2009. "Are Private Physicians More Likely to Veto Generic Substitution of Prescribed Pharmaceuticals?” Social Science \& Medicine 69: 1643-50.

Granlund, D. 2010. "Price and Welfare Effects of a Pharmaceutical Substitution Reform." Journal of Health Economics 29: 856-65. 
Granlund, D., and M. Y. Köksal-Ayhan. 2014. "Parallel Imports and Mandatory Substitution Reform - A Kick or a Muff for Price Competition?" The European Journal of Health Economics, Online First.

Granlund, D., and N. Rudholm. 2011. "Consumer Information and Pharmaceutical Prices: Theory and Evidence." Oxford Bulletin of Economics and Statistics 73: 230-54.

Granlund, D., and N. Rudholm. 2012. "The Prescribing Physician's Influence on Consumer Choice between Medically Equivalent Pharmaceuticals." Review of Industrial Organization 41: 207-22.

Hellerstein, J. K. 1998. "The Importance of the Physician in the Generic Versus Trade-Name Prescription Decision." RAND Journal of Economics 29: 108-36.

Jelovac, I., and C. Bordoy. 2005. "Pricing and Welfare Implications of Parallel Imports in the Pharmaceutical Industry." International Journal of Health Care Finance and Economics 5: 5-21.

Kanavos, P., and J. Costa-Font. 2005. "Pharmaceutical Parallel Trade in Europe: Stakeholder and Competition Effects.” Economic Policy 20: 751-98.

Leibowitz, A., W. G. Manning, and J. P. Newhouse. 1985. "The Demand for Prescription Drugs as a Function of Cost-Sharing." Social Science and Medicine 21: 1063-9.

Maskus, K. E., and Y. Chen. 2004. "Vertical Price Control and Parallel Imports: Theory and Evidence." Review of International Economics 12: 551-70.

Ministry of Health and Social Affairs, 2008. Regeringens proposition 2008/09:145, Omreglering av apoteksmarknaden [The government's bill 2008/09:145, reregulation of the pharmacy market (in Swedish). Accessed June 7, 2012, at http://www.regeringen.se.

Ministry of Health and Social Affairs, 2009a. Lag (2009:366) om handel med läkemedel [Law (2009:366) regarding trade of pharmaceuticals] (in Swedish). Accessed June 7, 2012, at http://www.riksdagen.se.

Ministry of Health and Social Affairs. 2009b. Lag (2009:373) om ändring i lagen (2002:160) om läkemedelsförmåner m.m. [Law (2009:373) about change in law (2002:160) regarding the pharmaceutical benefit scheme etc.] (in Swedish). Accessed June 1, 2012, at http://www. riksdagen.se.

Ministry of Health and Social Affairs. 2009c. Förordning (2009:659) om handel med läkemedel [Ordinance (2009:659) regarding trade of pharmaceuticals] (in Swedish). Accessed June 7, 2012, at http://www.riksdagen.se.

Mott, D. A., and R. R. Cline. 2002. "Exploring Generic Drug Use Behavior: The Role of Prescribers and Pharmacists in the Opportunity for Generic Drug Use and Generic Substitution." Medical Care 40: 662-74.

National Corporation of Swedish Pharmacies, The Federation of Swedish County Councils and the Pharmaceutical Benefits Board. 2004. Utbyte av läkemedel - En uppföljning av de första 15 månaderna med läkemedelsreformen. [Substitution of pharmaceuticals - The first 15 months of the substitution reform] Stockholm (in Swedish, electronic version). Accessed June 18, 2012, at http://www.tlv.se.

Pecorino, P. 2002. "Should the U.S. Allow Prescription Drug Reimports from Canada?" Journal of Health Economics 21: 699-708.

Pharmaceutical Benefits Agency, 2003.LFNFS 2003:1, Läkemedelsförmånsnämndens föreskrifter om ansökan och beslut hos Läkemedelsförmånsnämnden. [LFNFS 2003:1, The Pharmaceutical Benefits Agency's regulations about applications and decisions at the Pharmaceutical Benefits Agency] (in Swedish). Accessed July 6, 2012, at http://www.tlv.se. 
Pharmaceutical Benefits Agency, 2006. LFNAR 2006:1, General Guidelines Concerning Price Increases of Pharmaceuticals from the Pharmaceutical Benefits Board. Accessed July 6, 2012, at http://www.tlv.se.

Pharmacy Restructuring Corporation. 2009. Information about the Reregulation of the Swedish Pharmacy Market and the Sale of Pharmacies. Stockholm: Pharmacy Restructuring Corporation.

Raskovich, A. 2007. "Retail Buyer Power through Steering.” Economics Letters 96: 221-5.

The Committee on Health and Welfare. 2009.Socialutskottetsbetänkande2008/09:SoU21,

Omreglering av apoteks marknaden [The Committee on Health and Welfare's report 2008/ 09: SoU21, reregulation of the pharmacy market] (in Swedish). Accessed June 18, 2012, at http://www.riksdagen.se.

Varian, H. 1992. Microeconomic Analysis, 3rd ed. New York: W. W. Norton and Company. 